\title{
Climate Change, Biodiversity, and Tipping Points in Botswana
}

\author{
Peter Urich, Yinpeng Li, and Sennye Masike
}

\section{Contents}

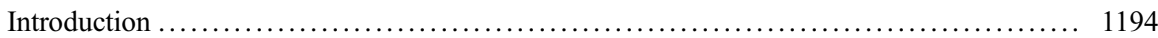

Tipping Points and Emergence ........................................ 1195

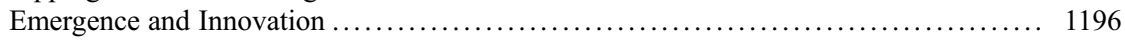

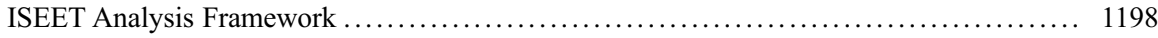

Institutional-Socio-Earth-Economical-Technical (ISEET) systems .................. 1198

The Working Definition of a Subsystem ................................... 1199

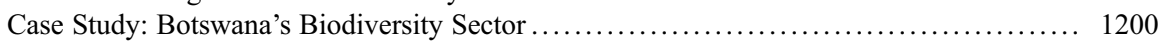

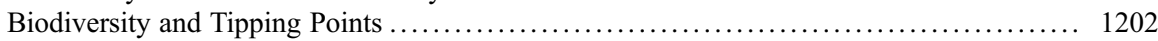

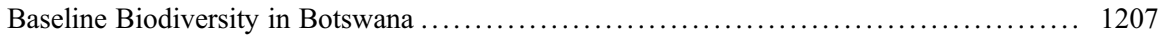

Biodiversity, Ecosystem Services, and Tourism ............................... 1210

Climate Change Impacts on the Biodiversity in Botswana ......................... 1212

One Example: The Okavango Delta ................................... 1213

Tipping Points for Climate Change for the Biodiversity Sector ..................... 1214

Results and Recommendations ....................................... 1214

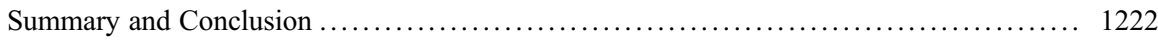

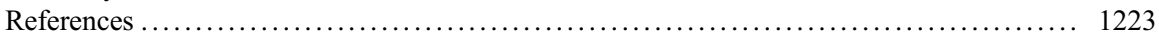

\section{Abstract}

Climate adaptation planning requires new ways of thinking and approaching the analysis of risks. Such thinking needs to be systemic in nature and practice/ action-oriented while respecting the complexity of the physical and social sciences. Through this chapter on climate tipping points in Botswana, it is proposed

This chapter was previously published non-open access with exclusive rights reserved by the Publisher. It has been changed retrospectively to open access under a CC BY 4.0 license and the copyright holder is "The Author(s)". For further details, please see the license information at the end of the chapter.

\section{P. Urich $(\bowtie) \cdot$ Y. Li $\cdot$ S. Masike}

International Global Change Institute and CLIMsystems Ltd, Hamilton, New Zealand e-mail: peter@climsystems.com; yinpengli@climsystems.com; sennye@climsystems.com 
that a generic and practice-oriented analysis framework be applied with a mathematical foundation including modeling methods based on complex science. The objective is to promote a framework that privileges a worldview to avoid biased and partial explanations of risks. An Institutional-Socio-Earth-EconomicalTechnical systems (ISEET) approach is based on a systems science philosophy for risk governance analysis, with particular emphasis on tipping points and emergence which are some of the key elements that can support sound adaptation planning. Through the lens of the biodiversity sector in Botswana, the complex interrelationships of ISEET principles are explained. They provide a new, efficient, and practical framework for moving rapidly from theory to action for planning and implementing climate change adaption projects.

\section{Keywords}

Tipping points $\cdot$ System dynamics - Climate change $\cdot$ Risk assessment $\cdot$ Biodiversity $\cdot$ Action research

\section{Introduction}

Humanity has modified the earth systems in significant ways and has initiated unprecedented Anthropocene risks (Keys et al. 2019; Baer and Singer 2018). Changes include fundamental aspects of the earth system such as all layers of the atmosphere, hydrosphere, and cryosphere through changes in weather patterns, climate, land surfaces, ocean chemistry, and geological structures. Anthropocene risks such as global connectivity either have reached or are approaching tipping points of various earth systems at different temporal and spatial scales (Steffen et al. 2018). Meanwhile, the emergence of new knowledge, technologies, and institutions has led to new approaches for problem-solving. An example of collective action is the Paris Agreement ratified by the United Nations Framework Convention on Climate Change (UNFCCC). However, progress in mitigating climate risk has not been satisfying. Responses are uneven and uncoordinated, and $\mathrm{CO}_{2}$ emissions continue to increase globally, even with green energy and other technological advancements. New approaches to the analysis of risks need to be articulated systemically and be practice-oriented while respecting the complexity of the physical and social sciences (Sterner et al. 2019; Lucas et al. 2018).

The existing initiatives and frameworks are limited, such as the Sendai Framework for Disaster Risk Reduction, the Paris Agreement, and international programs such as IRGP-IDHP (Integrated Risk Governance Project-International Human Dimension Programme). These limitations transcend the research frameworks as well, such as SES (socio-ecological system), STS (science technology and sustainability, and IAD (institutional analysis and development). The weaknesses of these existing frameworks as analysis and practice tools are being more widely debated and are modified as society seeks a better understanding of systemic risks posed by climate change and large-scale socio-physical disasters (Cole et al. 2014; McCord et al. 2017). 
A more generic and practice-oriented analysis framework is explored from a mathematical foundation, including modeling methods based on complex science. A structure of systems thinking applicable in the Anthropocene is proposed whereby analysis privileges a worldview and earth-view that attempt to avoid biased and partial explanations of risks.

\section{Tipping Points and Emergence}

There are standard features of systemic risks in different domains. These include the character of agents and emergence phenomena, tipping parameters indicating instability, and more noncommittal empirical observations. Instead, these features can be related as Lucas et al. (2018) describe on fundamental theory for relatively wellunderstood and straightforward systems in physics and chemistry. A crucial mechanism is the breakdown of macroscopic patterns of whole systems due to feedback reinforcing actions of agents on the microlevel, whereby the role of complexity science forms the basis for unifying the phenomena of systemic risks in widely different domains.

Tipping points sometimes also refer to shifting points. For example, the shift from an unsustainable to a sustainable society requires a radical historical change in the form of a profound transition which could involve a series of connected transitions in many socio-technical systems (e.g., energy, mobility, and food) toward sustainability. People who work from an SES point of view, studying the profound transition and radical change issues, use different expressions (Schot and Kanger 2018; van der Vleuten 2019).

According to Lenton et al. (2008: 1786), the term tipping point refers to a "critical threshold at which a tiny perturbation can qualitatively alter the state or development of a system." The following attributes are identified as tipping points in the Anthropocene:

- Tipping points could impact the whole planetary scale, everything living on Earth.

- Tipping points could impact the transition or the change of regime.

- Interaction crosses boundaries, including administration and nature systems and ISEETS boundaries.

- Both collective and individual social actions operate in multiple sociocultural, technological, governance, biophysical, and knowledge systems which interact with many other systems at the same time and many levels.

- Tàbara et al. (2018) focused on the complexity of attribution and a reductionist approach about systems thinking and the historical drive to an oversimplified explanation of solutions, drivers of tipping points that could improve the likelihood of limiting global warming to either the $1.5{ }^{\circ} \mathrm{C}$ or $2{ }^{\circ} \mathrm{C}$ target.

- When social and natural scientists collaborate and integrate their studies, new patterns and previously unforeseen relationships that can accentuate understanding have been achieved. Such studies often reveal intricate causes and effects as such works are based on well-defined spatial, temporal, and organizational units, 
be they culturally, physically, or politically determined. Another finding in such studies is their non-stationary and as Liu et al. (2009) feedback loops lag in effects from a range of identified causes and their relationship with resilience and thresholds can reveal new insights. It is also recognized that past interrelationships can have spillover effects that can continue to impact on not only a present state of a system but also its future.

- Tipping points are likely to be breached in the future; however, the underlying conditions are challenging to predict, and the accuracy in defining the time and place makes policy and decision-making currently inadequate for either mitigating or possibly avoiding transgressions.

- Thresholds are not constant. Instead, the position of a threshold along a determining variable can change. The consequences of crossing a threshold are context-dependent. The threshold is sometimes known, and the decision-making depends on the effects of crossing it.

- Tipping points or regime shifts are intricately related to the concept of system resilience.

\section{Emergence and Innovation}

Emergence plays a central role in theories related to integrative levels and complex systems. Emergence and emergent phenomena are essential concepts in complexity studies (Goldstein 2018). Emergence can be described as either the development or the presence of the existence or formation of common behaviors, whereby the collective actions within a system would not lead to a similar outcome if applied as individual, constituent parts with no recognized interaction. Emergence is also used to describe the properties of a system - what the system does under its relationship with the environment that it would not otherwise complete itself and is coupled to the scope and system boundaries (Ryan 2007). Emergence also refers to the ability of individual components of a system to collaborate, thus leading to rapid and diverse behavioral changes and new features. For the ISEET, more linkages and communication between subsystems, or the building of more relationships among the ISEET subsystems, could lead to new features emerging. These would then reflect the application of the more complex system and possibly more innovative systems thinking. Emergence is typically not reducible to, nor readily predictable from, the properties of individual system components. Therefore, it may appear surprising or unexpected (Halley and Winkler 2008). Emergent phenomena exist in all subsystems, which could provide solutions or options to the existing challenges in all subsystems if the emergence is managed properly (Ceccarelli et al. 2019; Lichtenstein 2014; Roundy et al. 2018).

Emergence could be applied in a conceptual framework. This framework could improve the understanding of scientific and technological progress (Alexander et al. 2012), innovation, and economic growth (Du and O'Connor 2019). Such a holistic innovation system could improve productivity through the diverse knowledge of 
business resources available. Emergence also could be scored to identify the topics and drivers of innovation (Porter et al. 2019).

The technology innovation process is central to effective adaption to climate change and development challenges. However, models from business and management tend to dominate innovation theory, which sits outside the adaption-development paradigm (Hope et al. 2018). The goal is, however, to support the development of sectoral and technologically detailed and policy-relevant country-driven strategies consistent with the UNFCCC Paris Agreement.

An ISEETS framework can be used to engage stakeholder input and buy-in; design implementation policy packages; reveal necessary technological, financial, and institutional enabling conditions; and support global stock-taking and ratcheting of ambition (Waisman et al. 2019).

Macro-level agreements, such as the UNFCCC Paris Agreement, should be designed to encourage debate on how to tackle climate change through the notion of innovation, applying both technological innovation and marketing issues. Innovation of a technical nature is part of the equation, but it is not the only requirement. It has been suggested by Asayehegn et al. (2017) that an enabling sectoral system of innovation (SSI) be prioritized where some technological innovations contribute to adaptation actions for climate change. Technological impact analysis could be included based on the following approaches: historical sectoral application and improvement on the systems, such as agriculture technology, livestock breeding and feeding technology, ICT technology, carbon sequestration technology, and others where appropriate.

With the emergence of adaptation technology, it can be defined as "the application of technology to reduce the vulnerability or enhance the resilience, of a natural or human system to the risks of climate change" (UNFCCC 2005: 5). Technologies are defined as either "hard" that includes equipment and infrastructure or "soft" such as institutions and management systems (Christiansen et al. 2011). However, some technologies, such as new crop varieties, are not so easy to categorize. Many technologies can be used to address current vulnerabilities to climate and other environmental, economic, and societal concerns and to reduce future exposure to climate change impacts. Some can also be used to address several types of climate change impact in different sectors.

ISEET modeling seems too big to be handled by either a single model or an existing framework. However, when considering specific modeling for a risk governance issue, the data, variables, and parameters could be selected and refined according to their importance and their functionalities. The modeling approaches from different disciplines could be either simplified or reorganized to fit specific purposes. For the subsystem in this chapter, the modeling approaches have been developed for specific contexts, which can be either absorbed or integrated into the ISEET modeling processes.

Modeling systemic or structural change in socio-environmental systems is not new. Tipping point modeling has been carried out by scientists from SES, climate systems, social systems, network analysis, and agent-based modeling disciplines. Based on the ISEET system analysis framework, Fig. 1 depicts an overview of an 


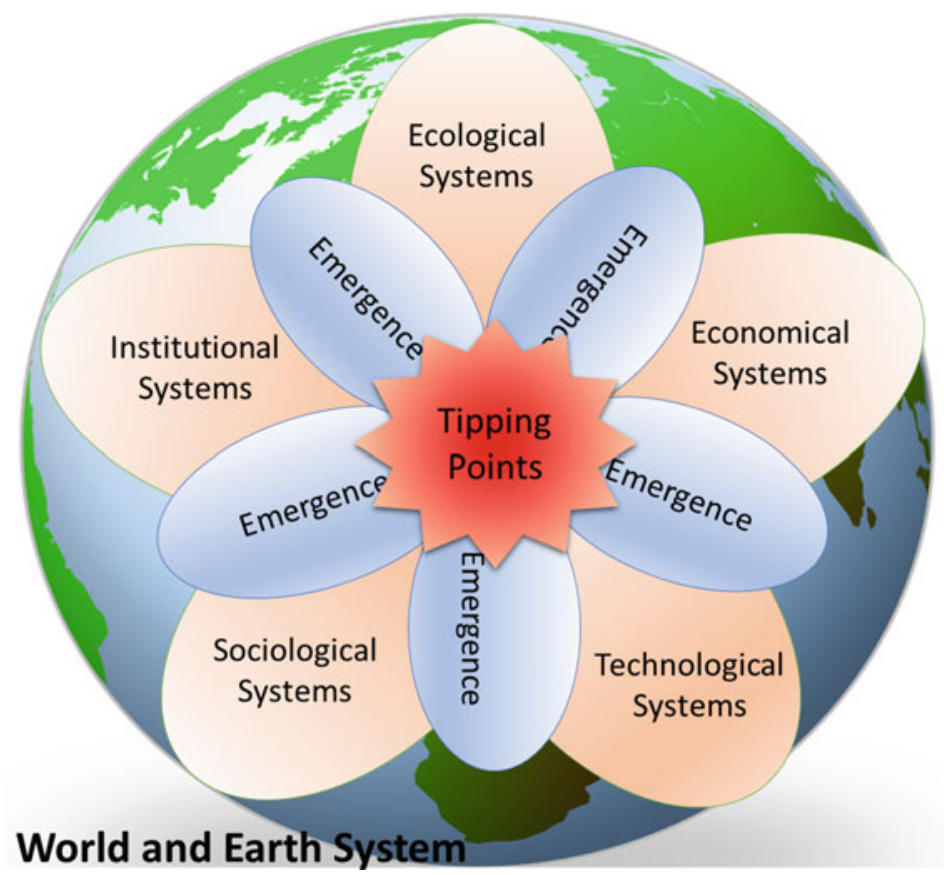

Fig. 1 The framework of Institutional-Socio-Economic-Ecological-Technological Systems (ISEETS) for a climate change tipping point study. (Source: authors)

ISEET structure for tipping points and the emergence of, and linkages between, five subsystems.

Tipping points and regime shifts are being studied within various disciplines applying a range of modeling approaches and analysis frameworks. One of the first obstacles in any study of systemic change is the terminology. Environmental and social science disciplines have engaged in relevant ideas of regime shift, structural change, non-marginal change, and transition theory, and each claims ownership (Polhill et al. 2016).

\section{ISEET Analysis Framework}

\section{Institutional-Socio-Earth-Economical-Technical (ISEET) systems}

ISEET describes five intrinsically interlinked systems formed around the Anthropocene. The method has at its foundation systems science concepts and mathematical methodologies for risk governance analysis, with emphasis on tipping points and emergence, which are the key characteristics that need to be analyzed for risk governance. 
ISEET represents a dynamic system. Their elements, functions, and relationships change with time and across spatial scales. Historical evidence and future prediction are essential for risk governance. Human beings do not always passively react to risks. With new and different technologies and the extension of knowledge, the risk may become more manageable. Opportunities could be created through the emergence mechanism in ISEET.

ISEET systems can be characterized as the coupling of natural laws with world rules. The goals are to support mutual well-being of the earth (physical) and world (social) systems. To describe risk governance issues in the Anthropocene, ISEET framework subsystems are indispensable. ISEET risk governance is either realized or implemented by institutions. They require the full engagement of societies and apply certain economically viable technologies that should encompass sustainable ecosystem service support from the earth environment and its resources.

From the subsystem point of view, the interrelationship could be described as:

- An institution that must have close collaboration with its relational society, using environmentally and ethically sound and economically viable technologies.

- Societies that could live with the environment, given effective and efficient institutions, and be economically healthy, with controllable risks on the earth system.

- Societies that need to work together to advance and apply technologies with economic endeavors, to live sustainably with the earth system.

- The sustainable development of economic systems that could be achieved by a well-designed and well-operated institution, which include social capital and earth resources.

- Technology that may need to be advanced and applied and that does not harm the environment and is ethically healthy. In this way, societies are more likely to promote institutions, with the input from their constituent economic systems.

\section{The Working Definition of a Subsystem}

- An institution in ISEET implies a body that operates within regulations, laws, policies, and conventions. Such institutions can represent cross-sectoral entities established when either developing or implementing a related risk governance framework. For example, emergency management laws and emergency management ministries are all part of a larger institutional system.

- Social systems in ISEET refer to all the elements, functions, and relationships in societies, including the population and its age and gender composition, culture, religion, educational level, and connectivity. Complexity theory offers the toolkit needed for this paradigm shift in social theory (Walby 2007).

- Earth system refers to the biophysical existence of the Earth planet, including the living support environment, from top air to deep earth.

- An economic system, as defined by Gregory and Stuart (2013: 30), "is a system of production, resource allocation and distribution of goods and services within 
a society or a given geographic area. It includes the combination of the various institutions, agencies, entities, decision-making processes and patterns of consumption that comprise the economic structure of a given community."

- Technological systems are sets of interconnected components that transform, store, transport, or control materials, energy, and information for specific purposes. Machines, software, and the hardware they run on are considered part of a technological system. Similarly, how humanity organizes itself to apply such technology are broader arrangements based on the organization's structures to exploit technology and techniques developed to optimize their application.

\section{Case Study: Botswana's Biodiversity Sector}

Time is of the essence for engaging in the intersection between climate change and the biodiversity extinction crisis. The Global Deal for Nature (GDN) is one opportunity as it is science-driven with the goal of saving the diversity and current relative abundance of life on the planet. The linkage of the GDN with the Paris Climate Agreement might help humanity avoid catastrophic climate change while conserving species and their increasingly recognized values, including ecosystem services.

Compelling recent findings add additional urgency to the issue as less than half of the globe's terrestrial realm is intact. The application of global climate points toward a tipping point. Habit conversions continuing as they were historically while greenhouse gas emissions maintaining its current trajectories may exceed humanity's chances of limiting global warming to the $1.5{ }^{\circ} \mathrm{C}$ target. Over the next 10 years, currently expanding conversion and poaching rates need to be slowed down considerably to avoid "points of no return" for some floral and faunal species (Fig. 2).

If global mean temperatures are permitted to rise above $1.5^{\circ} \mathrm{C}$, it is widely believed that fundamental aspects of ecosystems, both large and small, could unravel. Continued unsustainable use of the natural environment threatens our global health as witnessed by the rising risk of global pandemics, while mass migration owing to the lack of access to resources such as clean water and productive and uncontaminated land become more widespread. Global climate change and its increase in extreme events could accelerate the degradation of land and societies. For example, climate change-induced sea level rise and extreme still high-water events, which inundate coastal zones and droughts, may displace at least 100 million people by 2050 . Most of those people currently live in the southern hemisphere (Dinerstein et al. 2019).

Botswana, as part of Southern Africa, is home to an appreciable portion of global biodiversity, and many of its ecosystems retain relatively intact species assemblages across all trophic levels. The region possesses an established network of protected areas that contribute both to conservation targets and to nature-based tourism. Pressure on biodiversity can result from regional and highly localized developments concerning extractive resource use. Anthropogenic climate changes are more widely accepted as a profound driver of such impacts for Africa's biodiversity, including 


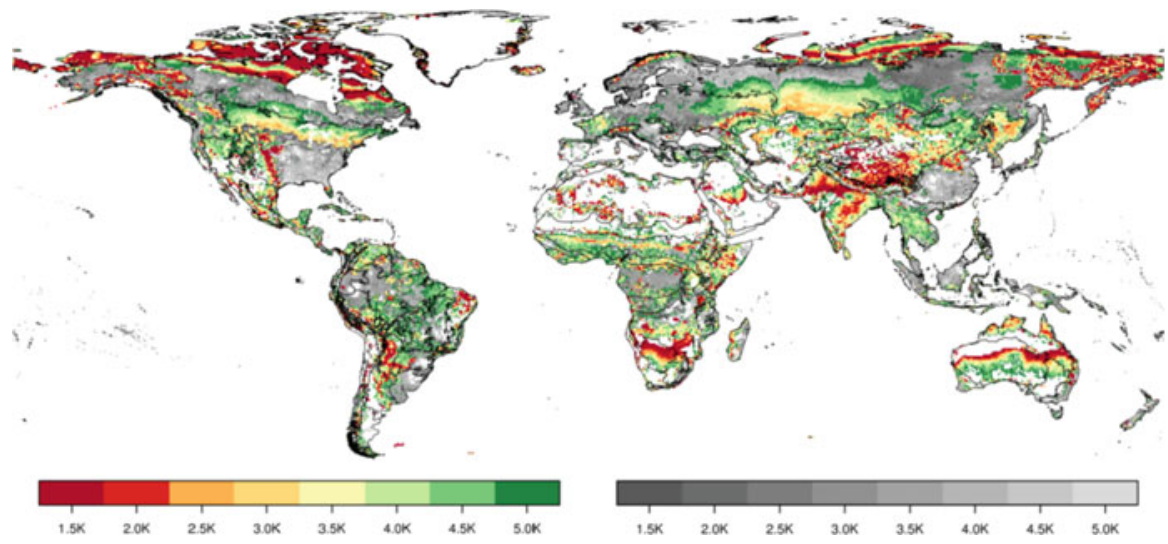

Fig. 2 Thresholds of temperature anomaly that could lead to significant local changes in landbased ecosystems. Colored areas (left legend) represent regions with severe transformation; gray areas (right legend) are likely to experience moderate transformation. Dark red transformation at $1.5^{\circ} \mathrm{C}$ and light red at $2.0^{\circ} \mathrm{C}$. (Courtesy of Gerten et al. 2013)

Botswana, and it is increasingly likely to be harmful from both ecological and economic perspectives.

Worldwide, the United Nations is committed to mainstreaming biodiversity planning in a wide range of policies and programs and with the inclusion of climate change. In a country such as Botswana, mainstreaming biodiversity and/ or wildlife management at the local, regional, and country level is critical to its economy and its place as a critical biodiversity REDD hotspot for several primary faunal species.

Botswana, in terms of biodiversity, is a country of contrasts. The diversity ranges from the wetlands of the north, dependent on water arriving season from neighboring Angola, to the broad and arid Kalahari Desert in the center and southwest. Each area is part of a systematic protected area system with the Okavango Delta representing the world's largest inland delta which is also a Ramsar site. At the same time, Chobe National Park has many varieties and populations of game and a considerable density of elephants. The country has innovated the first formally declared transboundary park in Africa, the Kgalagadi Transfrontier Park. There is also the Central Kalahari Game Reserve and the distinctive prehistoric lake that now consists of salt pans called the Makgadikgadi and Nxai Pans National Park system. This area has important habitats for migratory birds.

Botswana is developing a National Climate Change Policy, Strategy and Action Plan (NCCPSAP) with the framework for such being only recently devised. The policy will be implemented through the Ministry of Environment, Wildlife and Tourism in cooperation with the United Nations Development Programme. Among other objectives, the NCCPSAP aims to develop and implement appropriate adaptation strategies and actions that will lower the vulnerability of Botswana and various sectors of the economy to the impacts of climate change. 


\section{Biodiversity and Tipping Points}

Biodiversity in the context of tipping points is a complex area for investigation. Alternate stable states are associated with abrupt shifts in ecosystems, tipping points, and hysteresis, all of which challenge traditional approaches to ecosystem management (Oliver et al. 2015). Ecosystems often maintain their stability through internal feedback mechanisms. Environmental perturbations (natural and enhanced by climate change) can change the frequency and magnitude of regime shifts leading to fundamental changes in the assemblages of species providing functions.

Systems can be more susceptible to environmental randomness/irregularity and perturbations/fluctuation close to these critical tipping points and can lead to sudden changes and foster a new equilibrium. Such evolved alternative stable states might be unsupportive in terms of ecosystem functions with a return to a previous state only possible through substantial and costly management interventions (hysteresis). Therefore, the recovery capacity of ecosystem function can be compromised. Alternative conditions have been documented in a wide variety of ecosystems from local to global scales. However, how stable and persistent these will be in the future, under rapid changes in climate, remain uncertain.

It is exceedingly difficult to understand how complex ecosystems, for example, the Okavango Delta, will behave as they either approach or surpass tipping points (Fig. 3). Exceedingly small changes in one or more conditions can lead to a cascade of other changes resulting in a large shift in the state of the system. Sometimes this process can be played out very slowly and therefore less perceptibly by society, and at other times, extreme events lead to radical shifts that exceed the capability of systems to slowly recover, and hence it is forced to find a new stasis; this is a natural process with volcanic eruptions, earthquakes, and flood events often leading to abrupt changes. However, climate change and its speed of onset, which varies from location to location, and the uncertainty in future projections can lead to management paralysis. The slowing down of a potentially catastrophic collapse of individual and highly relevant parts of a system is therefore preferred to prolong the sustainability of the large system.

Ecosystem management depends on monitoring and maintaining resilience because the loss of resilience renders ecosystems more vulnerable to undesirable shifts. Several works summarized by Dai et al. (2012) suggest that a set of generic indicators may aid in the sustainable management of fragile ecosystems. Signals of critical slowing down based on time series demand observations over a long span. Compiling such data is often tricky; therefore, if other indicators based on the spatial structure can be identified, they could be complementary to the early warning signals.

Tipping points are often driven by either complex feedback mechanisms or interactions between multiple drivers. Some of these triggers or drivers are found to be new and thus are not well represented in models currently in use (Leadley et al. 2010). An example is a relationship between dying back in Amazon forests and deforestation and climate change processes that resulted in an underestimation of impacts in earlier global biodiversity assessments. This situation may pertain in the 


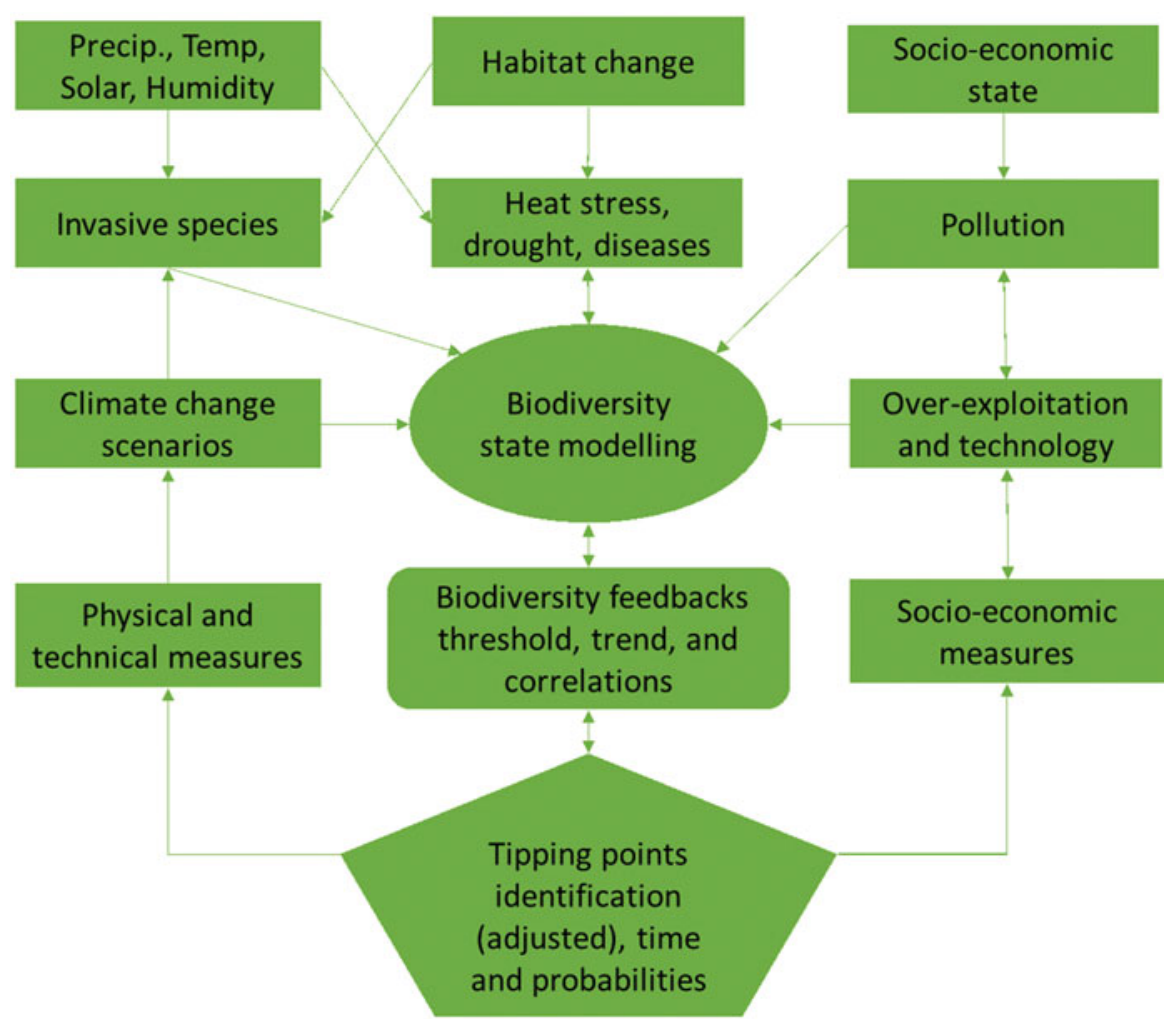

Fig. 3 Tipping point analysis framework for biodiversity in Botswana. (Source: authors)

case of the Okavango Delta where the sustained integrity of the Miombo woodlands on neighboring country of Angola leaves the well-established ecotourism focal areas such as the Okavango swamps in Botswana critically dependent on the sustained flow of sediment- and nutrient-free water from those upland parts of the wider river basin (Leadley et al. 2010).

Ecosystem service degradation can be linked with species extinctions, eroding species abundance, or as shown in this chapter potential shifts in biomes and associated species distributions. However, conservation of biodiversity and provision of some types of ecosystem services can conflict. The following tables list the already identified changes (from 2008 to 2019) in red category lists for plants and animals in Botswana in a limited African context (Tables 1, 2, and 3).

Midgley and Thuiller (2011) suggest significant impacts from unrestrained climate change for the southern part of the African region. However, overestimates of the speed of change and extent of those impacts may be the case owing to underlying assumptions of bioclimatic modeling. The analysis of a diverse range of studies does, however, support the rationale for a high level of concern as there is a signal across the available research that unmitigated changes in climate threaten a 


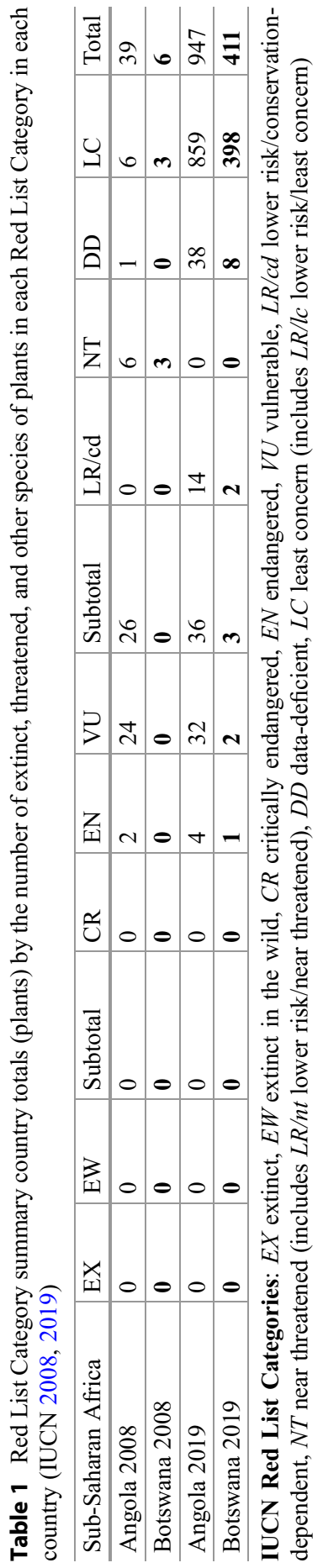




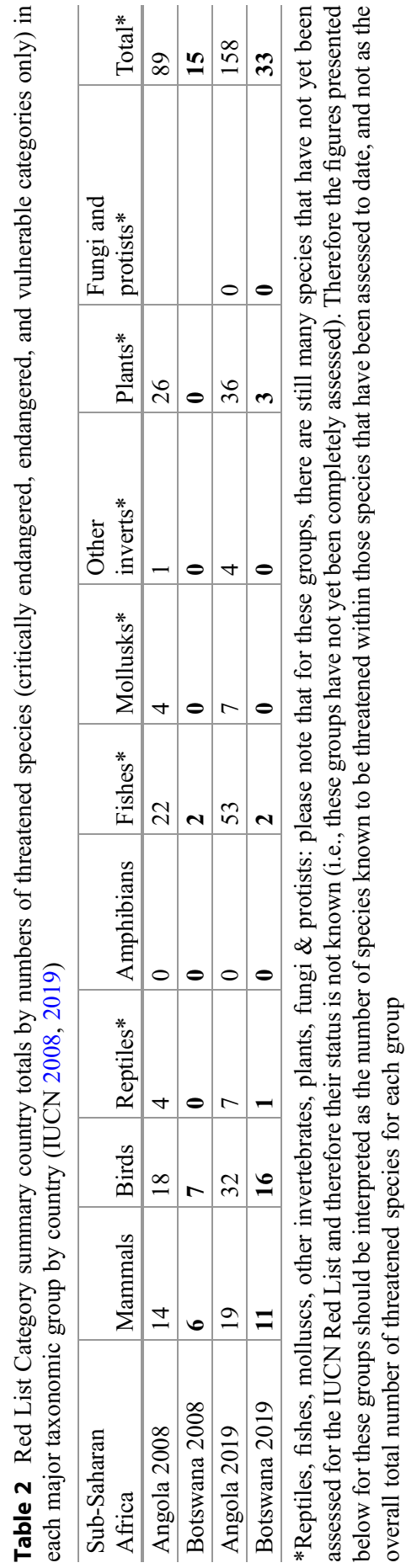




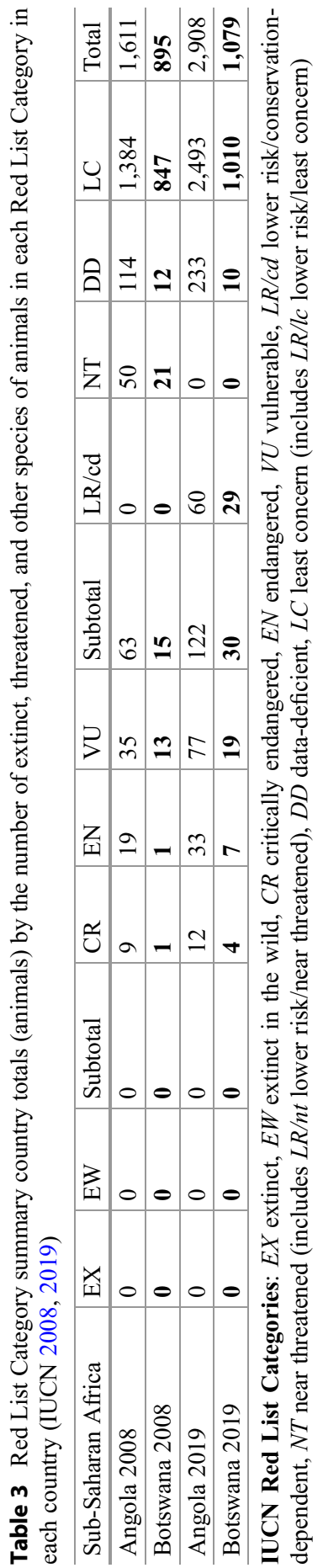


considerable portion of southern African biodiversity. It is the underlying shifts in ecosystem structures, for example, increases and decreases in woody plant cover, that have a secondary impact on faunal diversity that is likely to alter the dominant savanna vegetation type of the region. Midgley and Thuiller (2011) pointed to the winter rainfall areas of the broader region that could suffer the most significant biodiversity loss. The trends identified in Botswana are echoed in other biomes. It is increasingly recognized that rates of disturbance vary with time and can depend on long-term climate trends, the influence of anthropogenic land-use practices (e.g., fire), wildlife population cycles, and other factors such as presence or introduction of invasive species (Wilson et al. 2019). As noted by Wilson et al. (2019), assessment of regional patterns and trends is needed, hence our approach that placed Botswana in the context of Southern Africa. Specifically, some crucial areas are mostly outside Botswana, but they have relevant spillover effects, especially for the Okavango Delta.

Specifically, when mammals in the region are differentiated by size and dietary requirements, some more telling climate risks emerge. Correlations are significant for annual temperature but only for large mammals, where $60-67 \%$ of the variability in species richness of large mammals is impacted versus $<20 \%$ for small mammals (Andrews and O'Brien 2000). Small mammals are, however, strongly correlated with other either climatic or vegetation parameters. Plant richness, thermal seasonality, and frugivorous and insectivorous mammal richness are found to be correlated with thermal seasonality and minimum monthly PET (potential evapotranspiration). It is also found that arboreal and aerial species richness is associated with plant richness, thermal seasonality, and minimum monthly PET.

It is clear from Andrews and O'Brien's work (2000) that different classes of mammals respond to climatic and environmental factors in important ways. Earlier studies they contend did not identify these discrepancies, as the distinction between various sizes and guilds of mammal was not a common factor of analysis. With climate change, there will be issues across the diversity of mammalian species that should impact on their conservation in the future. This also points to the complexity of communities and the understanding of the potential importance of indicator species, whereby either a mammal's or other organisms' presence, absence, or abundance reflect on the environmental condition of either the ecosystem or biome. Such species can serve as critical indicators of tipping points in either an ecosystem or biome and act as a proxy for the health of that environment in the face of a changing climate.

\section{Baseline Biodiversity in Botswana}

Wide-ranging large carnivores are common in Botswana. They often range beyond the boundaries of protected areas into human-dominated areas. The mapping out on a country-wide scale and identifying areas with potentially high levels of threats to extensive carnivore survival is required when formulating national conservation action plans whether considering climate change or not. For this chapter, NPP (net 
primary production) in a historical context (and later in the context of climate change) has been linked with species biodiversity and richness.

This was done as the notion of NPP was linked with the country's large carnivore guild as part of a recent mapping project. In that project, Winterbach et al. (2014) identified and mapped areas consisting of leopard (Panthera pardus), lion (Panthera leo), cheetah (Acinonyx jubatus), brown hyena (Hyaena brunnea), spotted hyena (Crocuta crocuta), and African wild dog (Lycaon pictus) (Fig. 6). They discovered through this mapping project that habitat suitability for large carnivores depended primarily on prey availability but with secondary relationships with interspecific competition, plus conflict with humans. Winterbach et al. (2014) found that prey availability was a critical natural determinant. Wild ungulate species were preyed upon by the six large carnivores, and this helped to identify different management zones for large carnivore populations. The relationship with large ungulates and NPP

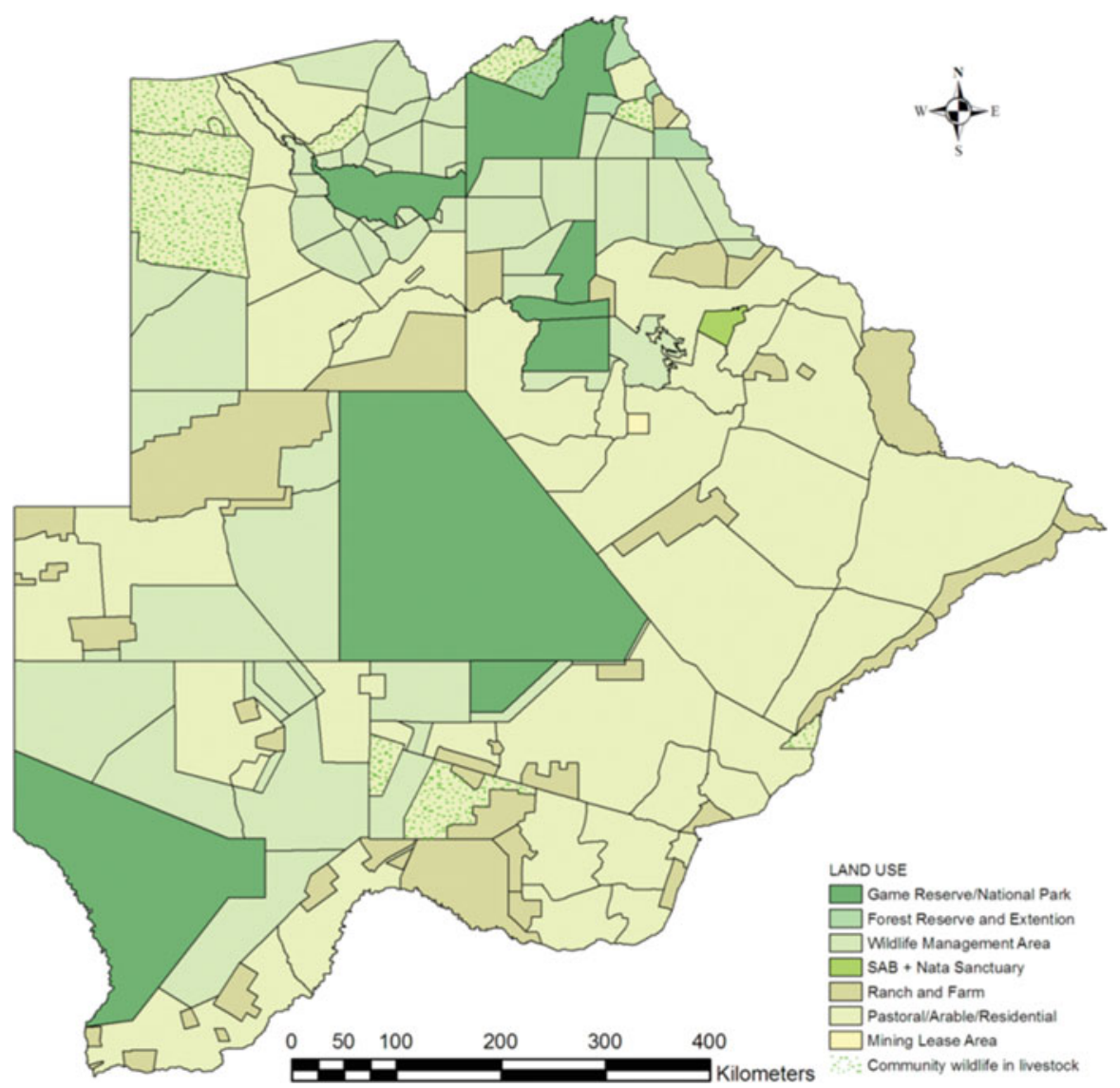

Fig. 4 Land-use zones in Botswana. (Courtesy of Winterbach et al. 2014) 
in the country is strong. Therefore, small prey biomass was more evenly spread across large parts of the country, while high to medium biomass of large prey was primarily confined to conservation zones (Figs. 4 and 5).

As Botswana is central, both geographically and in terms of species biodiversity of the larger Southern African sub-Congo basin, its ecological system was deemed prudent to map changes in net primary production and species richness regionally. Changes historically and in the future in these factors will mean transboundary issues will ensue. It is evident in Fig. 6 that mammal species richness is linked with regional phenomena such as NPP, annual precipitation, and mean changes in temperature. The future will be different; hence, some biome shifts from areas currently outside the borders of Botswana could encroach into Botswana over time and as temperatures rise. Clearly, this could lead to critical transboundary implications for management of the subsequent changes in floral and faunal biodiversity.

Future changes in the three zones of species richness in Botswana (Fig. 7) across three key indicator groups, mammals, birds, and amphibians, show clear patterns from the southwest (low richness across all three groups nationally) to moderate richness in the east and high richness in the north. Importantly, these three zones are not national boundary bound but extend to neighboring countries as shown in Fig. 7.

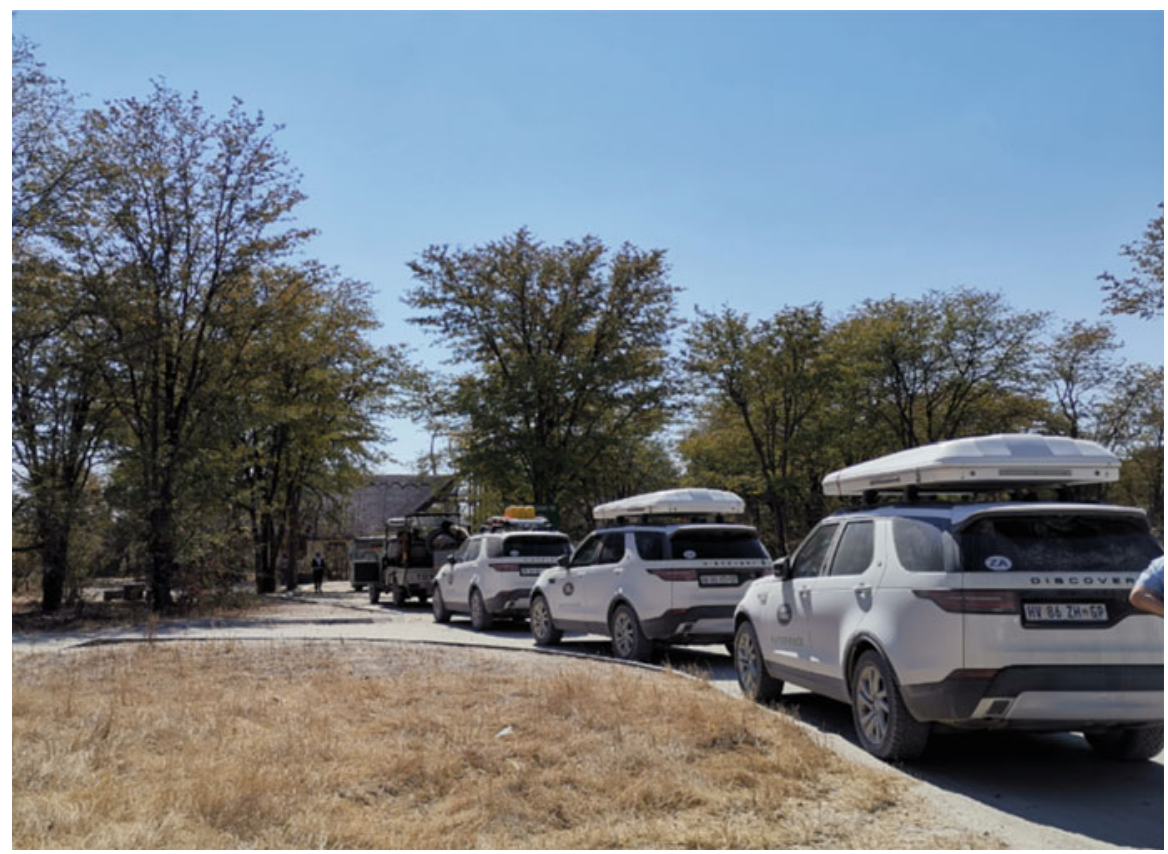

Fig. 5 Entrance to Moremi Reserve. (Source: authors) 


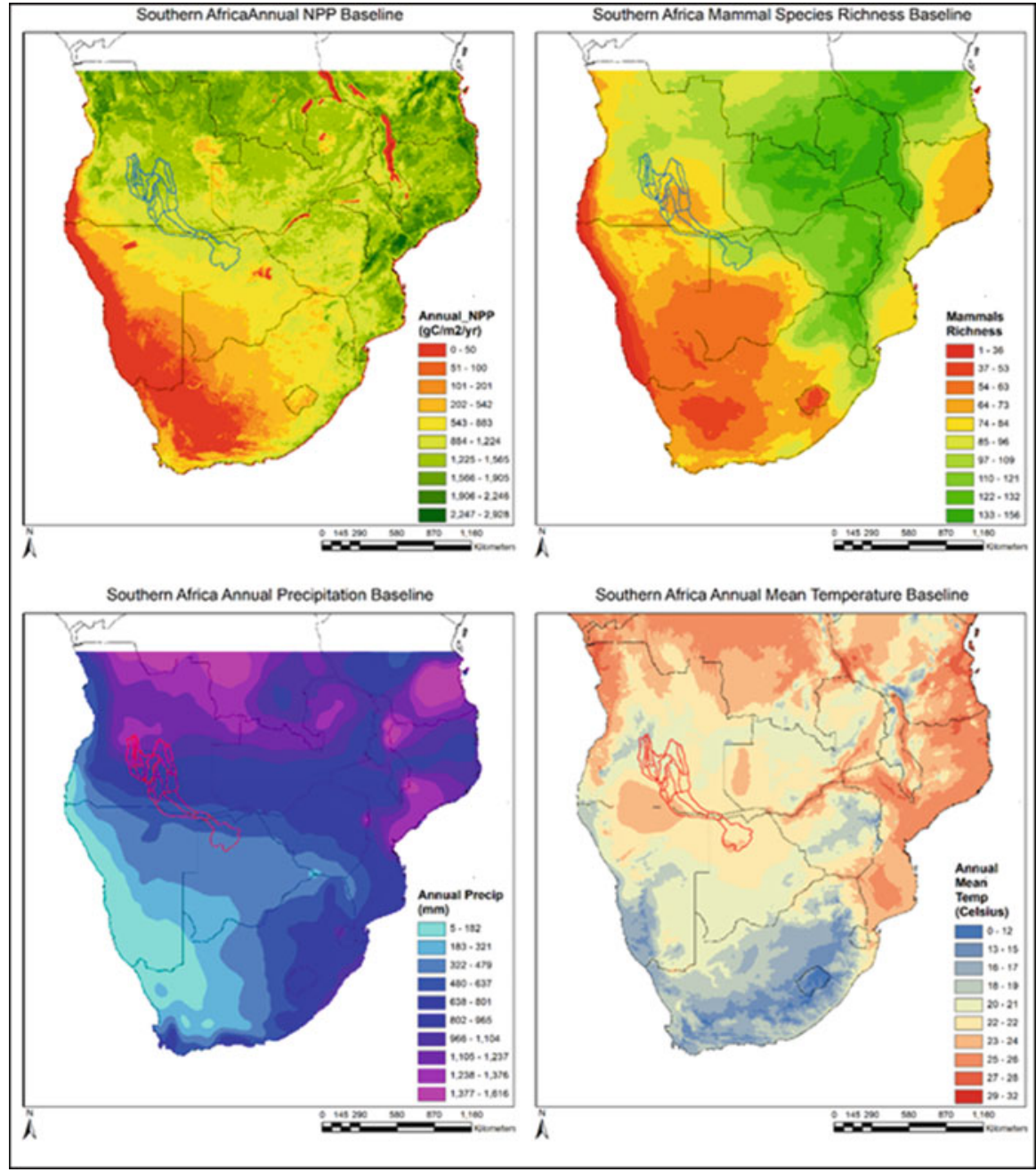

Fig. 6 Baseline NPP and the relationship between high values and mammal-specific richness, annual precipitation, and annual mean temperature. The Okavango River Basin that supports the Okavango Delta in Botswana is included as it is a key transboundary basin for Botswana species diversity and concomitant tourism and economic activities. (Source: authors)

\section{Biodiversity, Ecosystem Services, and Tourism}

Wildlife tourism in Botswana has provided strong economic incentives for conservation. With an abundance of wildlife and either the presence or absence of highprofile species, some zones are more suited to wildlife tourism. Winterbach et al. (2014) developed a set of parameters for assessing wildlife abundance and diversity. 


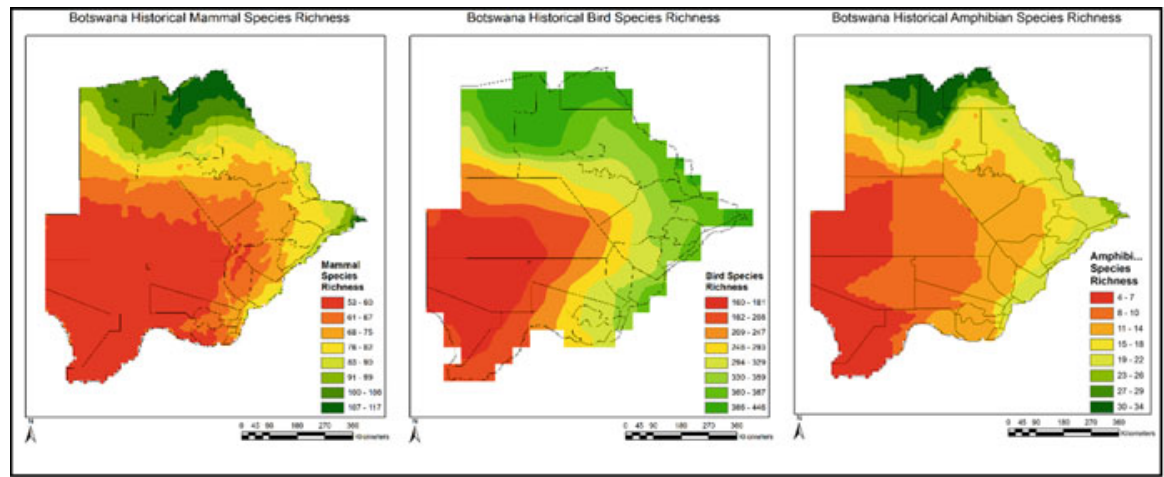

Fig. 7 Historical mammal. Bird and amphibian species richness highlight three key zones, the southwest (low), east (moderate), and north (high), and these three regions extend to neighboring countries. (Source: authors)

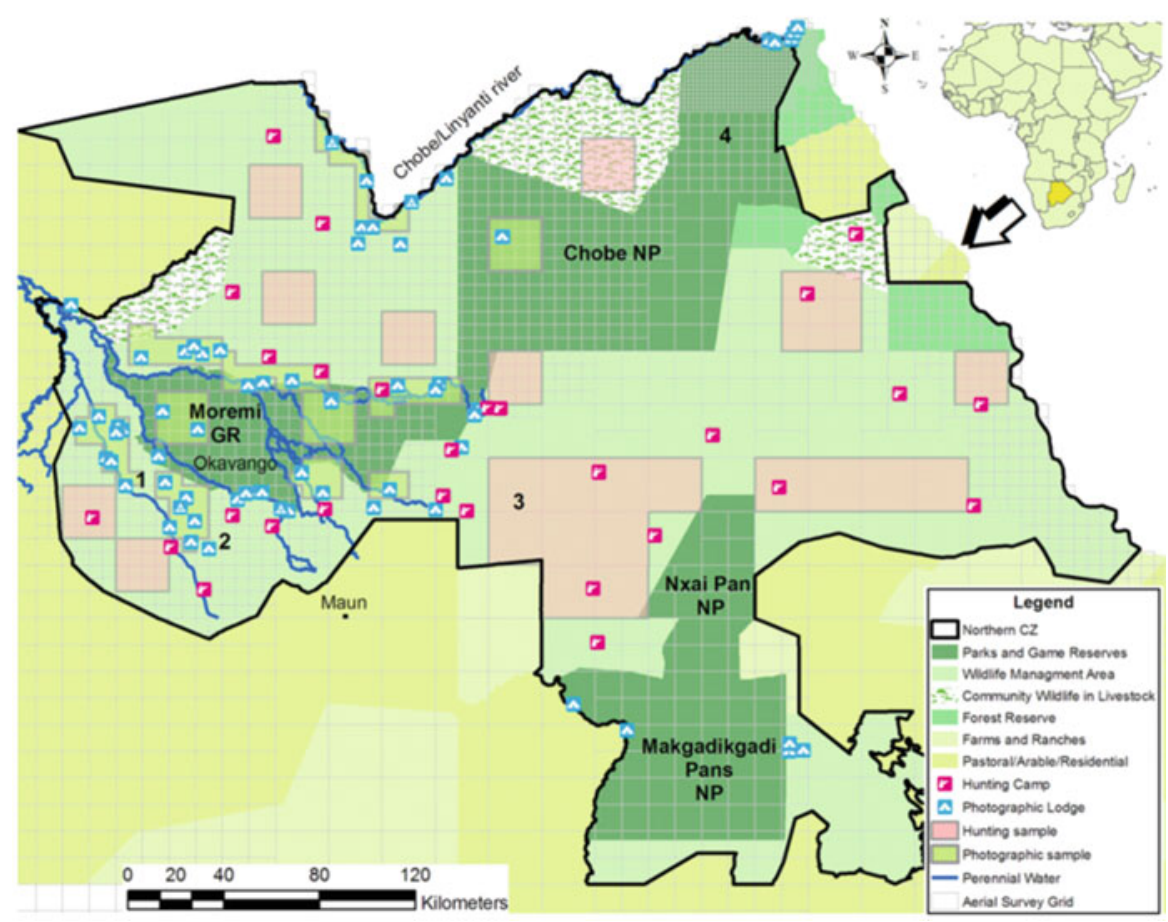

Fig. 8 Locations of photographic and hunting camps and land uses in northern Botswana in 2005. (Courtesy of Winterbach et al. 2015) 
Their goal was to evaluate tourism potential in Botswana's Northern Conservation Zone. They also quantified and compared tourism experiences in areas with high and low tourism potential. Wildlife biomass is used as an indicator of NPP, and actual tourism experiences were included in their study to validate their mapping exercise.

Winterbach et al. (2014) found that areas used for high-paying/low-volume tourism had significantly higher mean wildlife biomass and diversity (Fig. 8). Only $22 \%$ of the Northern Conservation Zone against their framework had intermediate to high tourism potential. High tourism potential areas afforded tourists better wildlife sighting based on aerial survey data than low wildlife sights based on ground surveys. They also found that the economic viability of low-paying tourism may not even be met in zones with intermediate to high tourism potential. Much of the Northern Conservation Zone was found to have low tourism potential; however, this does not equate with a low conservation value.

\section{Climate Change Impacts on the Biodiversity in Botswana}

Africa is expected to be particularly severely impacted by climate change (IPBES 2018). Biggs et al. (2008) assessed the impacts on terrestrial biodiversity using the Biodiversity Intactness Index (BII). This index defines an average change in population size against a pre-modern state, across all terrestrial species of plants and vertebrates. In the next 100 years, they projected a decline in average population sizes of taxa that exceed by two to three times the decline that occurred since circa 1700. A reduction in this modeled declines of biodiversity loss in southern Africa posed considerable challenges. Better alignment is needed for integrated biodiversity conservation and development priorities in the region. Furthermore, what is thought to be required are context-sensitive conservation targets that account for the development of imperatives in different parts of the region.

The predominant climate signal from the climate models for southern African is for a hotter and drier future. This is having, and will likely continue to pose, serious consequences and challenges for policy development and management of environmental and related social change for the people of the region. Historical climate records, as indicated, fit reasonably well with future projections for the region, with the important caveat that temperature rises are trending faster than the global mean, especially in continental interiors such as Botswana. Rainfall, however, apparently has not changed significantly, as yet although the combination of higher temperatures and the potential for changes in the variability of rainfall (e.g., more intense) and also changes in seasonality has already shown changes in the trends in vegetation trajectories in the major biomes of southern Africa. Contrary to early projections for the Succulent Karoo biome, biomass and cover increased over time. This was mainly deemed in response to changes in land-use practices. MacPherson et al. (2019) also found that the fire-adapted fynbos biome either remained stable or increased over time with some expansion of forest species.

Meanwhile, and in the same study, it was found that the shrub-dominated NamaKaroo biome increased in grass cover. Significantly, and in contrast with earlier 
model predictions, the grassland biome has expanded westward into former NamaKaroo biome sites. Regionally, the predominant savanna biome has experienced a relatively rapid increase in woody plants at rates initially unexpected by climate/ vegetation models (MacPherson et al. 2019). The availability of new model parameters for biomes and net primary production also provide a useful context for evaluating future changes and for considering tipping points.

Climate change and adaptation have also become a significant issue in contemporary tourism development and policy discussions. This is particularly the case in Botswana and the broader geography of Southern Africa where wildlife in its natural environment dominate the sector. A study on perceptions of climate change (Saarinen et al. 2012) and adaptation strategies of tourism operators in Kgalagadi South District, of southwest Botswana, which also looked at their adaptation strategies, found a general awareness, but the research was conducted nearly 10 years ago. At that time, most operators did envisage challenges to future business growth and Botswana's tourism competitiveness. The perception is that climate change did not at that time have any impacts and that few adaptation strategies were in place. Anecdotal evidence from the consultant's time spent in the Okavango Delta (2019) with a tourism operator of considerable experience pointed to heightened concern regarding climate change. However, problems with earthquake impacts and climate change were signaled as underlying factors in reduced water flow into various parts of the Delta.

\section{One Example: The Okavango Delta}

The Government of Botswana has adopted a policy of economic diversification, which is reflected in the National Development Plan 8. There is a strong emphasis on the sustainable use of renewable resources such as veld products and wildlife. Tourism has been identified as a potential "engine for growth" (Jones 2017) and that tourism is based on wildlife and nature experiences. There is an increasing emphasis on the conservation and sustainable use of these resources with a strong geographic focus on the Okavango Delta.

There are significant variations in the size of the actual wetland seasonally as well as from year to year, depending on rainfall intensities in the watershed and other factors (McCarthy 2003). About half of the wetland is permanently inundated, whereas the other half is only seasonally flooded (Anderson et al. 2003); the two areas are referred to as the permanent swamp and the seasonal swamps, respectively.

The Okavango Delta is important ecologically as well as economically. The remoteness, spectacular landscape, and richness in wildlife make the Okavango Delta a magnet for tourists, and tourism has become the second most important sector of the Botswana economy.

Climate change and development-induced land-use change are explicit threats to sustaining biodiversity (Newbold 2018). Modeling and data limitations have hampered a better understanding of the underlying systemic risks. Also problematic are the quite different scales at which land-use and climate processes operate. Newbold 


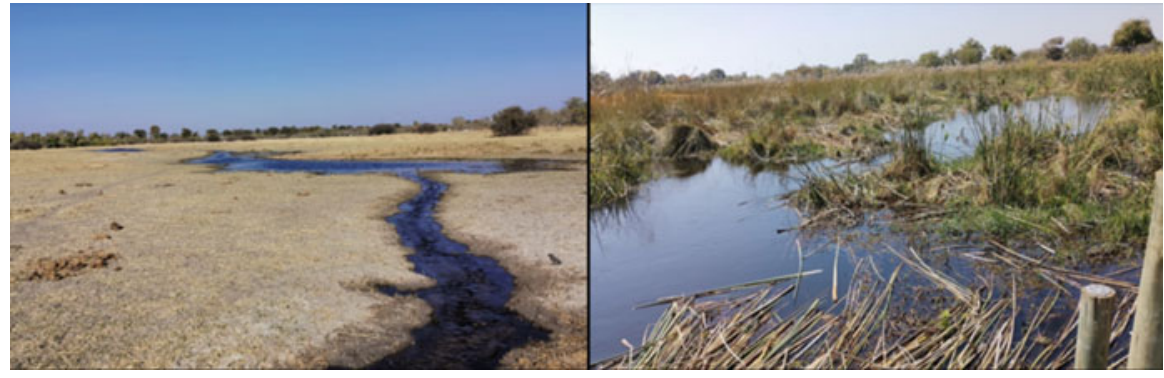

Fig. 9 Differentiation in water distribution within the Delta. (Source: authors)

(2018) predicted that climate change effects will become a significant pressure on biodiversity and could exceed the effects of land-use change by 2070 . Both pressures were predicted to lead to an average cumulative loss of $37.9 \%$ of species from vertebrate communities under a "business as usual" scenario with an uncertainty range from $15.7 \%$ to $54.2 \%$. The biomes to face the most significant pressures were tropical grasslands and savannahs (Fig. 9).

\section{Tipping Points for Climate Change for the Biodiversity Sector}

\section{Results and Recommendations}

Climate change is already well advanced in Botswana and has already created new challenges for biodiversity conservation. Evidence shows that two key elements that are driven by changes in climate are in a national-scale tipping point analysis: shifting biomes and changes in species composition that relates to net primary production of specific environments. Owing to the complexity of biodiversity and variability of species richness across the country, it was only possible to define broad relationships in terms of potential tipping points.

As mentioned, the dominant relationship between net primary production and biome shifts with the potential to support stable biodiversity mixes is complicated. Natural succession of species must be disentangled from a complex web of confounding factors including a plethora of human factors as well as a relatively rapid change in climate regimes. There appears to be emerging a maturing of the science related to shifts on biomes with changes in climate and signals are thus becoming more transparent that climate has a more dominant role to play in the transition of landscapes and hence biodiversity.

The mapping of mammalian, bird, and amphibian species in Botswana (Fig. 7) with modeled climate-induced changes in net primary production provides insights into possible future changes as temperatures continue to rise regionally. Of note, the temperature profiles of $1.5^{\circ} \mathrm{C}, 2.0^{\circ} \mathrm{C}$, and $3.0^{\circ} \mathrm{C}$ are presented in the introduction and are expected to be reached under current business as usual scenario (84th percentile) (RCP 8.5) in roughly 2028, about 2036, and around 2050, 
respectively. There will, of course, be lag times in the response regarding average net primary production in the regions and subsequent potential shifts in biodiversity, barring any management interventions and other human dimensions of change that could ensue over the next 30 years.

The trend in net primary production, which is a driving factor in species richness, is for expansion from southwest to northeast of the lower productivity zone. Concurrently, across all three future temperature profiles, the higher NPP areas of the east and north also become progressively less productive. The same trends are then seen in Fig. 7 where the mammalian species richness diminishes nationwide, i.e., there are no parts of the country that with a temperature change should expect to see an expansion in species richness under natural conditions and changes in the net primary production. Again, these projections are made barring human dimensions of change and its management interventions. The same situation pertains to bird and amphibian species richness with a general overall reduction nationwide but with a general trend of a decline in net primary production from the southwest to northeast.

The change in NPP and species richness while following these trends also presents the opportunity to look contemporarily at areas with current NPP and species richness and consider how economic development strategies may intersect when the conditions found in one area expand into others and transition other biomes and communities. Therefore, there are current activities in the zones that will develop that may present insights for the future as these zones shift into new geographies. Given the relative homogeneity of the Botswanan topography, such transitions could expect to vary relatively little from current forms as they expand. Importantly, there is a change in NPP at the $3.0^{\circ} \mathrm{C}$ tipping point that is different. In all the species richness projections (Fig. 7) at this degree of warming, a new low-end species richness category could exist in Botswana that is currently not represented. This is presented in the species richness maps as the $42-48$ category for mammalian and bird species richness and the 2-4 range for amphibian species richness. Areas with these ranges of species richness could be found to the west and southwest of Botswana currently, but analysis would need to be done to see if these are, in fact, presently located in the broader region or this new low-end category is currently unknown in the area (Figs. 10, 11, 12, and 13).

Related to the shifts in NPP and species richness described above, the ranges and ecological dynamics of the country are changing, and current reserves will possibly struggle to support all species they were designated to sustain. Climate is, however, just one of the myriads of ISEET issues that impinge on the sustainability of Botswana's biodiversity. Action to mitigate the deterioration in biodiversity varies by spatial scale and the actors required. It is generally viewed that adaptation will require more and better regional institutional coordination, which broadens spatial and temporal perspectives with climate chance scenarios being considered as integral to the planning of actions. Local communities are critical to attaining conservation goals, as there are multiple threats to success. Regional planning, site-scale management, and the continued assessment and modification of conservation plans 


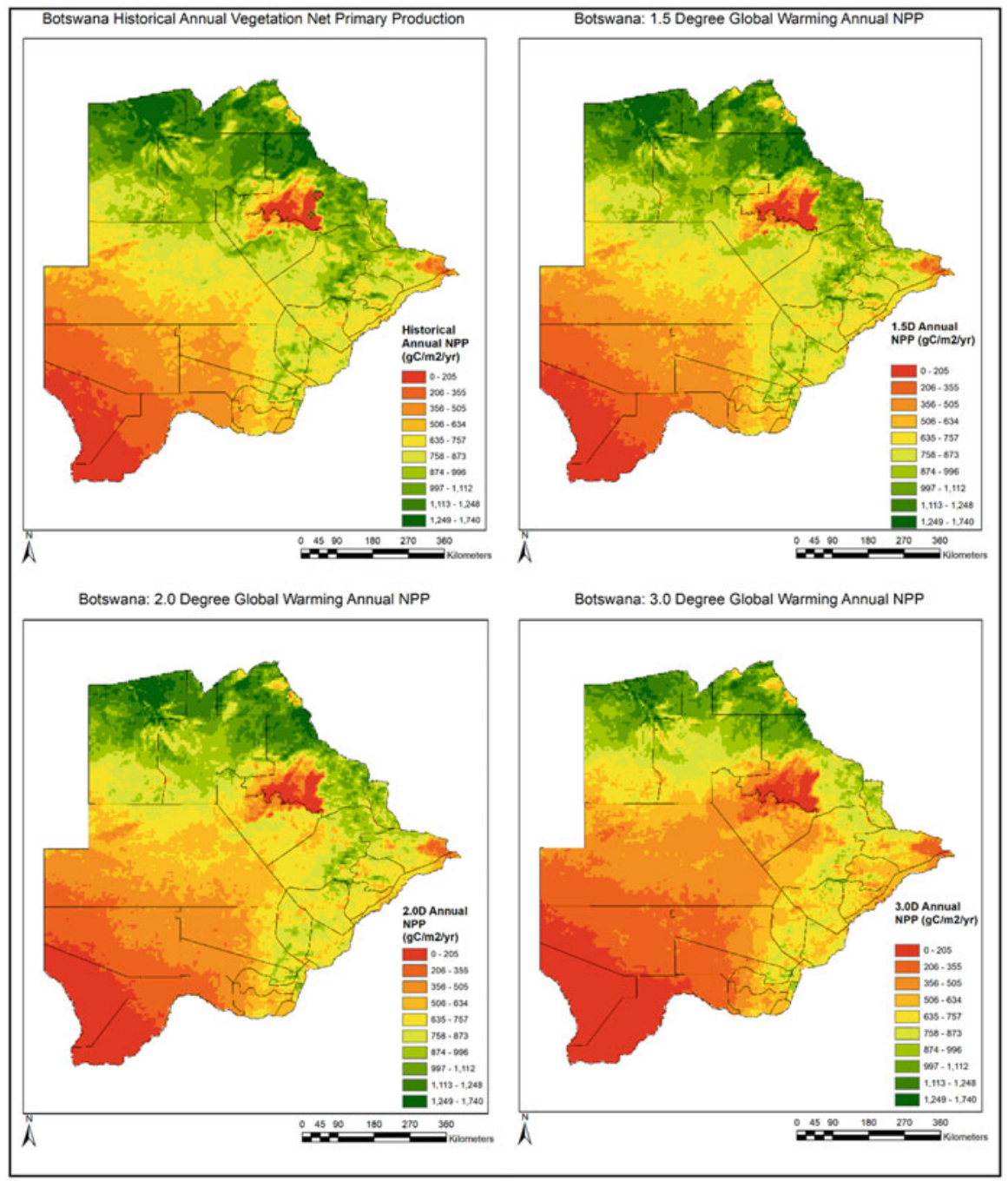

Fig. 10 Changes projected for net primary production (NPP) under the three tipping point scenarios of $1.5^{\circ} \mathrm{C}, 2{ }^{\circ} \mathrm{C}$, and $3{ }^{\circ} \mathrm{C}$, from baseline (average of 2000-2016). (Source: authors)

will be required as the pace of climate-induced changes mirror those of society. The following needs have been identified:

(1) more specific, operational examples of adaptation principles that are consistent with unavoidable uncertainty about the future;

(2) a practical adaptation planning process to guide the selection and integration of recommendations into existing policies and programs; and,

(3) greater integration of social science into an endeavor that, although dominated by ecology, increasingly recommends extension beyond reserves and into human-occupied landscapes. (Heller and Zavaleta 2009: 14) 


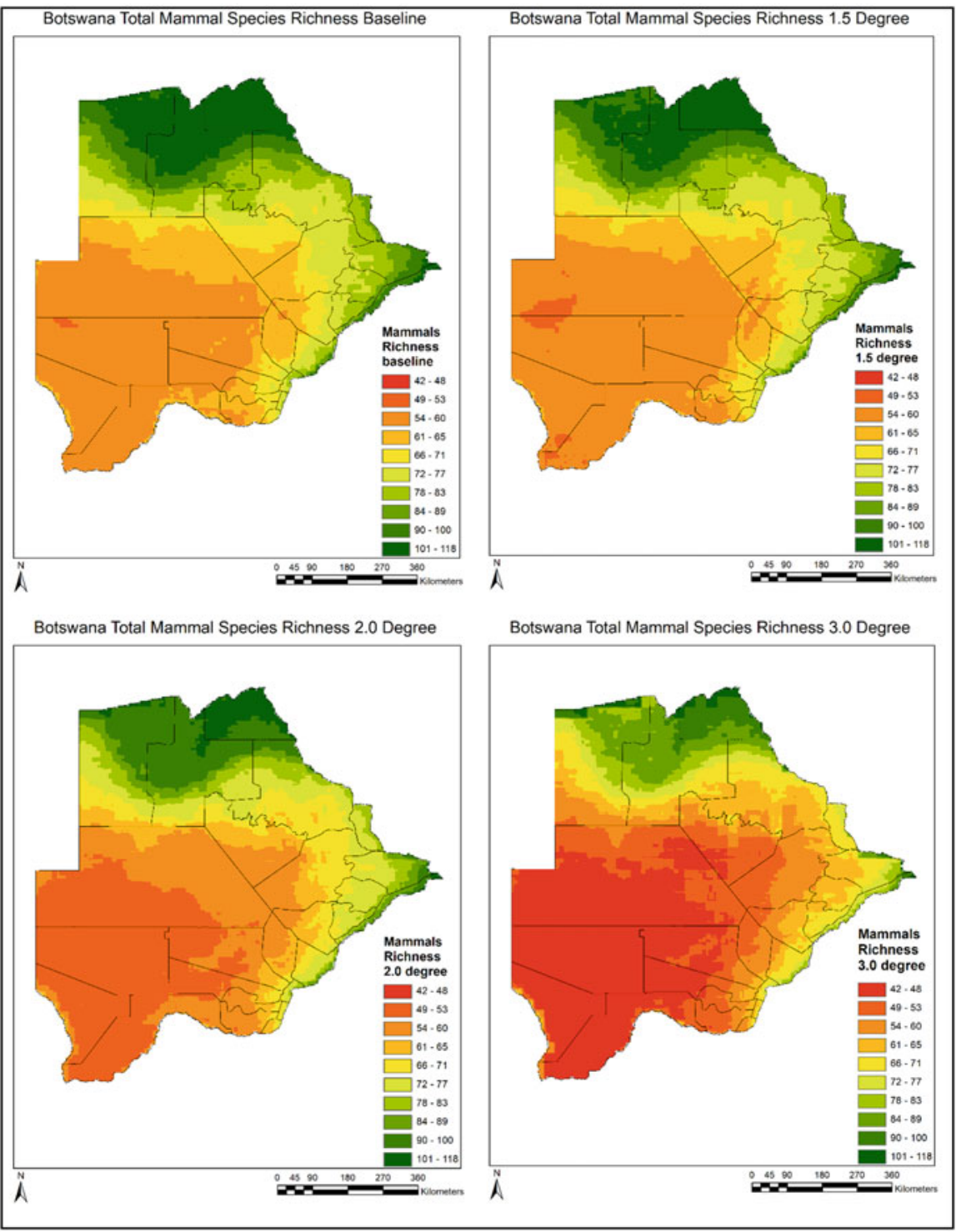

Fig. 11 Changes projected for mammalian species richness under the three tipping point scenarios of $1.5^{\circ} \mathrm{C}, 2{ }^{\circ} \mathrm{C}$, and $3{ }^{\circ} \mathrm{C}$, from baseline. (Source: authors)

The Paris Agreement is deemed to be beneficial to the cause of species biodiversity conservation as it represents a template for a GDN by setting global targets, an evolving model for financial support, and recognizes the values obtained from bottom-up efforts. Nearly all nations have signed the agreement. Climate scientists have arrived at a single numerical target for maintaining Earth's atmosphere at safe 


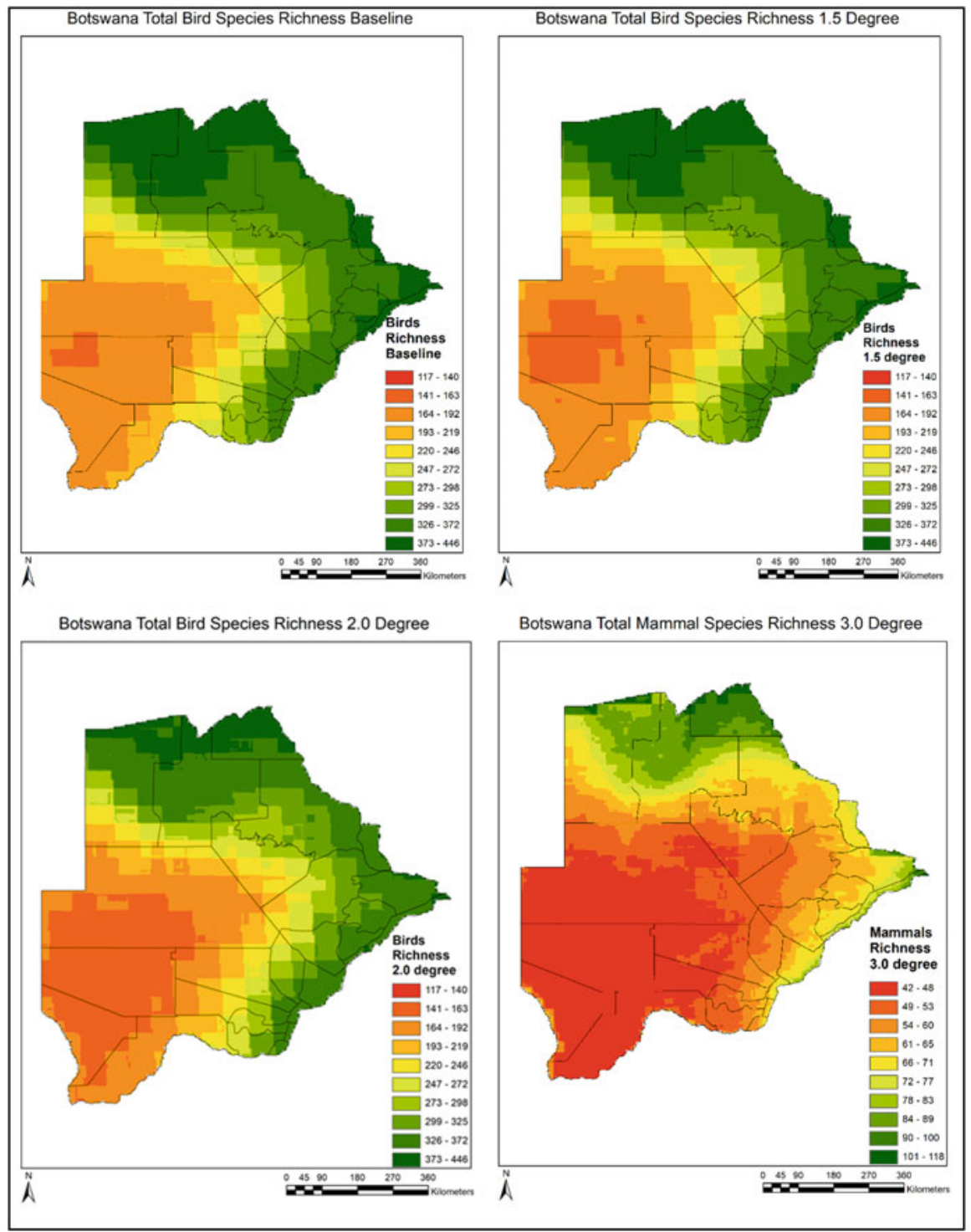

Fig. 12 Changes projected for bird species richness under the three tipping point scenarios of $1.5{ }^{\circ} \mathrm{C}, 2{ }^{\circ} \mathrm{C}$, and $3{ }^{\circ} \mathrm{C}$, from baseline (note: data source available is at a different resolution than mammalian and amphibian sources, hence the different map smoothness). (Source: authors)

limits $\left(1.5^{\circ} \mathrm{C}\right)$; however, biodiversity scientists work with multiple targets to conserve the rest of life on the planet given the diversity of life and ecosystems and range of resilience. The challenge clearly shown in the case of biodiversity in Botswana is the interconnectedness of the nation with the southern African region 


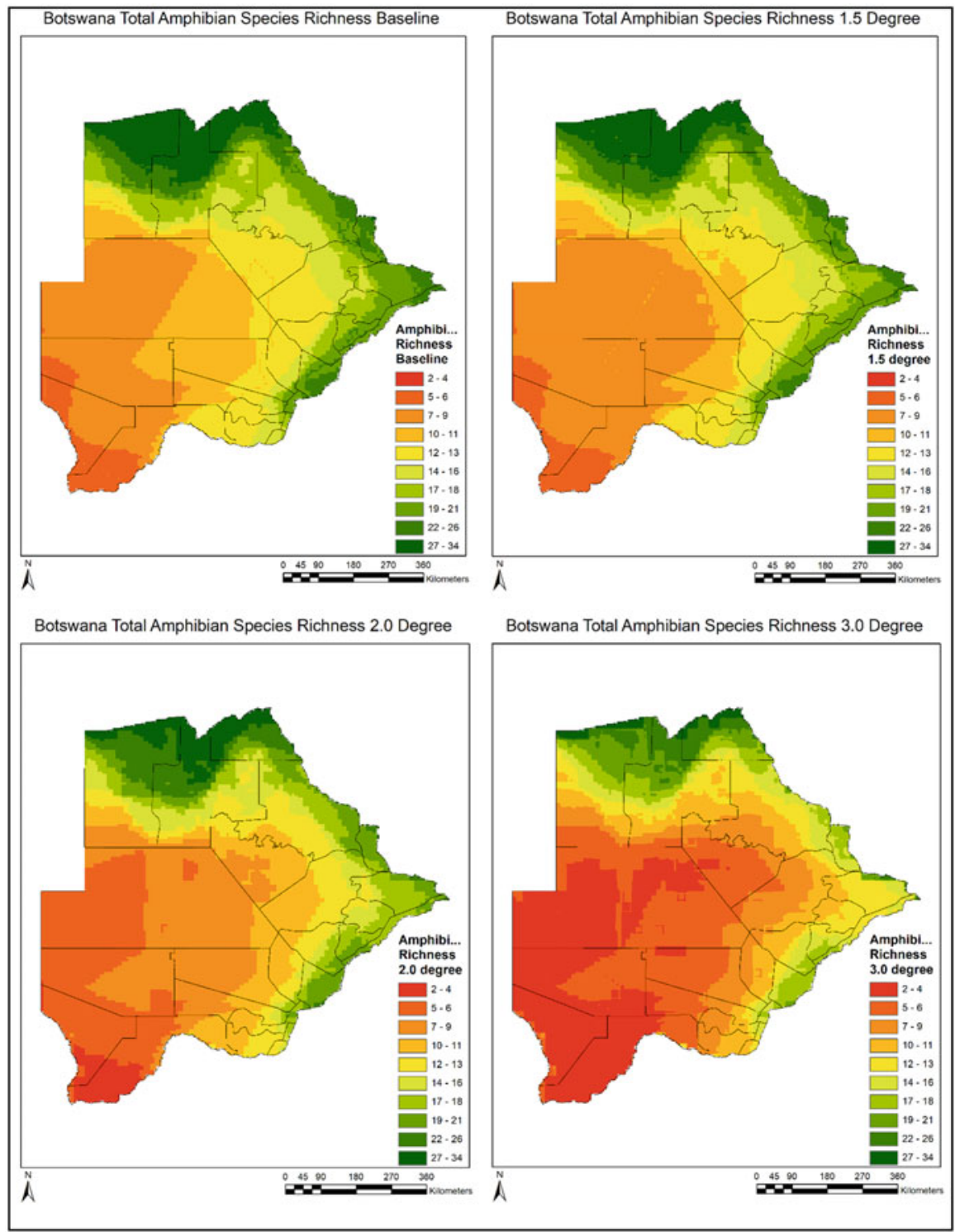

Fig. 13 Changes projected for amphibian species richness under the three tipping point scenarios of $1.5^{\circ} \mathrm{C}, 2{ }^{\circ} \mathrm{C}$, and $3{ }^{\circ} \mathrm{C}$, from baseline. (Source: authors)

and the faster than global average rise in temperatures. The international climate science goal of limiting global temperatures to $1.5^{\circ} \mathrm{C}$ by 2100 is not relevant for places such as Botswana that could reach that average rise in temperature as early as 2028. The GDN has expressed its own target like the Paris Agreement: protect at least half of Earth's biodiversity by 2050 and ensure that these areas are connected 
Table 4 Biodiversity sector tipping point analysis summary table

\begin{tabular}{|c|c|c|c|c|}
\hline Impact factors & Slow processes & Variabilities & Extremes & $\begin{array}{l}\text { Potential tipping } \\
\text { points }\end{array}$ \\
\hline $\begin{array}{l}\text { Earth systems } \\
\text { (climate } \\
\text { change): } \\
\text { Threshold } \\
\text { risks }\end{array}$ & $\begin{array}{l}\text { Biodiversity } \\
\text { decrease } \\
\text { vegetation } \\
\text { primary } \\
\text { production, land } \\
\text { degradation, } \\
\text { access to water, } \\
\text { heat stress, } \\
\text { diseases, tourism } \\
\text { and agriculture } \\
\text { land pressure, } \\
\text { conflict }\end{array}$ & $\begin{array}{l}\text { International } \\
\text { variability } \\
\text { increase, death } \\
\text { rate increase, } \\
\text { diseases, } \\
\text { poaching }\end{array}$ & $\begin{array}{l}\text { Extreme } \\
\text { drought and } \\
\text { diseases (foot } \\
\text { and mouth) } \\
\text { events } \\
\text { Low water flows } \\
\text { in Okavango } \\
\text { Delta } \\
\text { Wildlife } \\
\text { movements/ } \\
\text { encroachments } \\
\text { to cropping } \\
\text { areas }\end{array}$ & $\begin{array}{l}\text { Continuous } \\
\text { drought years } \\
\text { could cause the } \\
\text { wildlife high } \\
\text { death rate and } \\
\text { migration }\end{array}$ \\
\hline $\begin{array}{l}\text { Earth systems } \\
\text { (climate } \\
\text { change): } \\
\text { Potential } \\
\text { adaptation } \\
\text { options }\end{array}$ & $\begin{array}{l}\text { Recover and } \\
\text { reserve natural } \\
\text { habitats for } \\
\text { natural earth } \\
\text { systems }\end{array}$ & $\begin{array}{l}\text { Provide } \\
\text { alternative } \\
\text { areas/substantial } \\
\text { buffer zones for } \\
\text { ecosystem } \\
\text { change and } \\
\text { succession }\end{array}$ & $\begin{array}{l}\text { System integrity } \\
\text { enhancement to } \\
\text { support } \\
\text { biodiversity } \\
\text { resilience at } \\
\text { times of climatic } \\
\text { stress }\end{array}$ & $\begin{array}{l}\text { Species } \\
\text { migration } \\
\text { pattern shifts } \\
\text { Species decline } \\
\text { and extinction } \\
\text { Increased } \\
\text { human/ } \\
\text { biodiversity } \\
\text { conflict }\end{array}$ \\
\hline $\begin{array}{l}\text { Social } \\
\text { systems: } \\
\text { Threshold } \\
\text { risks }\end{array}$ & $\begin{array}{l}\text { Tourism sector } \\
\text { dependency, } \\
\text { livestock number } \\
\text { increase, rural } \\
\text { labor force, and } \\
\text { food relationship }\end{array}$ & $\begin{array}{l}\text { Tourism natural } \\
\text { conservation } \\
\text { and human } \\
\text { conflicts }\end{array}$ & $\begin{array}{l}\text { Wildlife } \\
\text { decrease during } \\
\text { an extreme } \\
\text { drought event }\end{array}$ & $\begin{array}{l}\text { Dramatic } \\
\text { changes in } \\
\text { tourist sector } \\
\text { behavior } \\
\text { Loss of } \\
\text { economic } \\
\text { tourism } \\
\text { opportunity } \\
\text { without changes } \\
\text { in location and } \\
\text { interaction with } \\
\text { species }\end{array}$ \\
\hline $\begin{array}{l}\text { Social } \\
\text { systems: } \\
\text { Potential } \\
\text { adaptation } \\
\text { options }\end{array}$ & $\begin{array}{l}\text { Tourists and local } \\
\text { people education } \\
\text { and behavior } \\
\text { regulation }\end{array}$ & $\begin{array}{l}\text { Natural and } \\
\text { human } \\
\text { relationship } \\
\text { education and } \\
\text { behavior } \\
\text { regulation }\end{array}$ & $\begin{array}{l}\text { Reduce human } \\
\text { impacts, support } \\
\text { system natural } \\
\text { recovery where } \\
\text { is possible }\end{array}$ & $\begin{array}{l}\text { Biodiversity and } \\
\text { tourism sector in } \\
\text { collaboration } \\
\text { with other } \\
\text { ISEET for } \\
\text { systematic } \\
\text { analysis and } \\
\text { uplift social } \\
\text { system support }\end{array}$ \\
\hline
\end{tabular}


Table 4 (continued)

\begin{tabular}{|c|c|c|c|c|}
\hline Impact factors & Slow processes & Variabilities & Extremes & $\begin{array}{l}\text { Potential tipping } \\
\text { points }\end{array}$ \\
\hline $\begin{array}{l}\text { Institutional } \\
\text { system: } \\
\text { Threshold } \\
\text { risks }\end{array}$ & $\begin{array}{l}\text { Deficiency and } \\
\text { out of date in } \\
\text { biodiversity } \\
\text { protection } \\
\text { legislation and } \\
\text { policy, land-use } \\
\text { and planning } \\
\text { legislation and } \\
\text { policy }\end{array}$ & $\begin{array}{l}\text { Government } \\
\text { policy and } \\
\text { institutional } \\
\text { implementation } \\
\text { capacity }\end{array}$ & $\begin{array}{l}\text { Institutional } \\
\text { dramatic } \\
\text { changes }\end{array}$ & Policy failure \\
\hline $\begin{array}{l}\text { Institutional } \\
\text { system: } \\
\text { Potential } \\
\text { adaptation } \\
\text { options }\end{array}$ & $\begin{array}{l}\text { Balanced policy } \\
\text { and regulation } \\
\text { and } \\
\text { implementation } \\
\text { capacity for } \\
\text { biodiversity } \\
\text { protection and } \\
\text { tourism } \\
\text { development }\end{array}$ & $\begin{array}{l}\text { Policy and } \\
\text { regulations } \\
\text { support the } \\
\text { resiliency of the } \\
\text { biodiversity } \\
\text { conservation } \\
\text { that allows } \\
\text { natural system } \\
\text { recovery }\end{array}$ & $\begin{array}{l}\text { Reinforce and } \\
\text { stabilize } \\
\text { institutional } \\
\text { system, } \\
\text { prepared for } \\
\text { emergencies }\end{array}$ & $\begin{array}{l}\text { Work together } \\
\text { with closely } \\
\text { linked ISEET } \\
\text { systems, to } \\
\text { build the robust } \\
\text { institutions for } \\
\text { biodiversity } \\
\text { conservation } \\
\text { and tourism }\end{array}$ \\
\hline $\begin{array}{l}\text { Economic } \\
\text { systems: } \\
\text { Threshold } \\
\text { risks }\end{array}$ & $\begin{array}{l}\text { Tourism sector } \\
\text { over development } \\
\text { Irrational land- } \\
\text { use and } \\
\text { agriculture } \\
\text { development }\end{array}$ & $\begin{array}{l}\text { International } \\
\text { tourism market } \\
\text { variations. } \\
\text { Changed } \\
\text { habitats and } \\
\text { protected area } \\
\text { systems too } \\
\text { rigid for } \\
\text { continuous } \\
\text { protection of } \\
\text { biodiversity as } \\
\text { biomes shift }\end{array}$ & $\begin{array}{l}\text { Market collapse, } \\
\text { financial crisis }\end{array}$ & $\begin{array}{l}\text { International } \\
\text { financial crisis } \\
\text { Tourist air travel } \\
\text { depressed by } \\
\text { GHG } \\
\text { accounting and } \\
\text { social pressure } \\
\text { to reduce flying }\end{array}$ \\
\hline $\begin{array}{l}\text { Economic } \\
\text { systems: } \\
\text { Potential } \\
\text { adaptation } \\
\text { options }\end{array}$ & $\begin{array}{l}\text { Financial } \\
\text { regulation for } \\
\text { overdevelopment } \\
\text { and land } \\
\text { development }\end{array}$ & $\begin{array}{l}\text { Economic } \\
\text { measures for } \\
\text { sustainable } \\
\text { tourism and } \\
\text { biodiversity } \\
\text { protection } \\
\text { subsidies and } \\
\text { compensation } \\
\text { incentives }\end{array}$ & $\begin{array}{l}\text { Tourism sector } \\
\text { support and } \\
\text { alternative work } \\
\text { development }\end{array}$ & $\begin{array}{l}\text { Overarching } \\
\text { economic and } \\
\text { financial } \\
\text { arrangement for } \\
\text { biodiversity and } \\
\text { tourism, in } \\
\text { coordination } \\
\text { with ISEET } \\
\text { systems }\end{array}$ \\
\hline
\end{tabular}


Table 4 (continued)

\begin{tabular}{|c|c|c|c|c|}
\hline Impact factors & Slow processes & Variabilities & Extremes & $\begin{array}{l}\text { Potential tipping } \\
\text { points }\end{array}$ \\
\hline $\begin{array}{l}\text { Technological } \\
\text { systems: } \\
\text { Threshold } \\
\text { risks }\end{array}$ & $\begin{array}{l}\text { Wildlife and } \\
\text { biodiversity } \\
\text { conservation } \\
\text { technology } \\
\text { improvement } \\
\text { Human } \\
\text { intervention at a } \\
\text { large scale to } \\
\text { enhance } \\
\text { biodiversity } \\
\text { management } \\
\text { regimes }\end{array}$ & $\begin{array}{l}\text { Technology } \\
\text { insufficiency } \\
\text { Maladaptation } \\
\text { in the } \\
\text { management of } \\
\text { biodiversity and } \\
\text { conservation }\end{array}$ & $\begin{array}{l}\text { Technology } \\
\text { failure } \\
\text { Species collapse } \\
\text { from linked with } \\
\text { wider } \\
\text { environmental } \\
\text { collapse from } \\
\text { extreme heat } \\
\text { and drop in net } \\
\text { primary } \\
\text { production }\end{array}$ & $\begin{array}{l}\text { Huge } \\
\text { biodiversity loss } \\
\text { by technological } \\
\text { system failure } \\
\text { Disease } \\
\text { outbreak and } \\
\text { biome changes } \\
\text { lead to mass } \\
\text { extinction } \\
\text { events and loss } \\
\text { of keystone } \\
\text { species }\end{array}$ \\
\hline $\begin{array}{l}\text { Technological } \\
\text { systems: } \\
\text { Potential } \\
\text { adaptation } \\
\text { options }\end{array}$ & $\begin{array}{l}\text { Sustainable } \\
\text { knowledge and } \\
\text { technology } \\
\text { applications } \\
\text { development and } \\
\text { introduction for } \\
\text { biodiversity and } \\
\text { tourism }\end{array}$ & $\begin{array}{l}\text { Development } \\
\text { and introduction } \\
\text { of the } \\
\text { knowledge and } \\
\text { technologies for } \\
\text { resilient } \\
\text { biodiversity and } \\
\text { tourism sectors }\end{array}$ & $\begin{array}{l}\text { Technology } \\
\text { improvement } \\
\text { and backup } \\
\text { mechanisms }\end{array}$ & $\begin{array}{l}\text { Technology } \\
\text { innovation and } \\
\text { knowledge } \\
\text { gaining for } \\
\text { ISEET system } \\
\text { stabilization }\end{array}$ \\
\hline
\end{tabular}

(Dinerstein et al. 2019). Over time the role of intact, diverse systems has been repeatedly demonstrated, and they are integral to carbon storage and hence the link to the Paris Agreement. For Botswana, intactness and linkages regionally will become increasingly relevant and urgent given the accelerating pace of temperature and other changes facing the country, which are well ahead of the global trends (Table 4).

\section{Summary and Conclusion}

The implications of climate change are a growing concern for biodiversity managers in Botswana. Even simple extrapolation of current trends in temperature makes clear that a warming climate can have negative impacts on many facets of Botswana's society and ecosystems. The sum of these troubling effects, although highly uncertain, motivates efforts to assess and manage potential climate change impacts.

Climate change may trigger major social transformations. As seen around the globe, both slow-onset climate change and extreme weather events can, for example, induce food and water insecurity. Subsequent riots, mass movements of people, and pressure on governance systems to respond to limit social anxiety and loss of national cohesion are being increasingly researched.

However, it is not a simple, one-to-one relationship. The relationship between climate and biodiversity and social change is not easy to identify. The scale of climate change that can induce significant and consequential change and related calls 
to action, including social transformations, may be minor or major. Often it is built-in resiliency of Institutional-Socio-Economic-Ecological-Technological Systems (ISEETS) that determines if a drought, flood, fire, epidemic disease, or another extreme event will trigger a societal response.

Climate change experts such as Tim Lenton pioneered the use of the term tipping points to refer to "abrupt and irreversible changes in the climate system." The concept has been taken further than climate knowledge to further our understanding of the consequences of climate change. What are often overlooked in climate change research are the social determinants of changes, for example, inequities in determining the social impacts of climate change. Also ignored are perceptions and (mis) representations of change in whatever form that might be, as well as governance systems and institutions, solidarity networks, and cultural values, and underlying technological condition and opportunities in their evaluation of the future social impacts of climate change.

The experience of those interested in biodiversity in Botswana forms a recent historical example of how ecological tipping points are identified and sometimes managed historically ineffectively but with increased local and specific cultural and environmental awareness, more effectively. What are, therefore, more challenging to determine are the social tipping points that would potentially lead to more accurate assessments of the future impacts of climate change. This then expands the thinking about climate change to more fully grasp the biological effects of a changing climate and our technological capacity to forecast them and respond more effectively.

News has emerged on the recognition of the cross-sectoral importance of a more resilient Okavango ecological system which is encouraging. The signing in 2019 of the three-country pact to work, titled "Transboundary cooperation for protecting the Cubango-Okavango River Basin and improving the integrity of the Okavango Delta World Heritage," properly championing an integrated approach to the entire river basin management is an important step forward (Kari and Kaboza 2019). The actors and agents involved and their perspectives represent an ISEET-like approach. The follow-up activities of implementation of defining activities and their monitoring and evaluation will be critical. Time is running out as climate change and its impacts accelerate across Southern Africa.

\section{References}

Alexander J, Chase J, Newman N, Porter A, Roessner JD (2012) Emergence as a conceptual framework for understanding scientific and technological progress. In: 2012 Proceedings of PICMET'2: technology management for emerging technologies, pp 1286-1292

Anderson RL, Foster DR, Motzkin G (2003) Integrating lateral expansion into models of peatland development in temperate New England. J Ecol 91(1):68-76

Andrews P, O’Brien EM (2000) Climate, vegetation, and predictable gradients in mammal species richness in southern Africa. J Zool 251(2):205-231

Asayehegn K, Iglesias A, Triomphe B, Pédelahore P, Temple L (2017) The role of systems of innovation in adapting to climate change: the case of the Kenyan coffee and dairy sectors. $\mathrm{J}$ Innov Econ Manag 3:127-149

Baer HA, Singer M (2018) The anthropology of climate change: an integrated critical perspective. Routledge, London 
Biggs R, Simons H, Bakkenes M, Scholes RJ, Eickhout B, van Vuuren D, Alkemade R (2008) Scenarios of biodiversity loss in southern Africa in the 21st century. Glob Environ Chang 18 (2):296-309

Ceccarelli A, Zoppi T, Vasenev A, Mori M, Ionita D, Montoya L, Bondavalli A (2019) Threat analysis in systems-of-systems: an emergence-oriented approach. ACM Trans Cyber Phys Syst 3(2):18

Christiansen L, Olhoff A, Trærup S (eds) (2011) Technologies for adaptation: perspectives and practical experiences. UNEP Risø Centre, Roskilde

Cole DH, Epstein G, McGinnis MD (2014) Toward a new institutional analysis of social-ecological systems (NIASES): combining Elinor Ostrom's IAD and SES frameworks. Indiana legal studies research paper, no. 299; Indiana University, Bloomington School of Public and Environmental Affairs research paper, no. 2490999. Indiana University, Bloomington School of Public \& Environmental Affairs, Bloomington

Dai L, Vorselen D, Korolev KS, Gore J (2012) Generic indicators for loss of resilience before a tipping point leading to population collapse. Science 336(6085):1175-1177

Dinerstein E, Vynne C, Sala E, Joshi AR, Fernando S, Lovejoy TE, ... Burgess ND (2019) A global deal for nature: guiding principles, milestones, and targets. Sci Adv 5(4):eaaw2869

Du K, O'Connor A (2019) Examining economic complexity as a holistic innovation system effect. Small Bus Econ. https://doi.org/10.1007/s11187-019-00215-z

Gerten D et al (2013) Asynchronous exposure to global warming: freshwater resources and terrestrial ecosystems. Environ Res Lett 8:034032

Goldstein JA (2018) Emergence and radical novelty: from theory to methods. In: Handbook of research methods in complexity science. Edward Elgar Publishing, Cheltenham

Gregory P, Stuart R (2013) The global economy and its economic systems. South-Western Cengage Learning, Boton, MA

Halley JD, Winkler DA (2008) Classification of emergence and its relation to self-organisation. Complexity 13(5):10-15

Heller NE, Zavaleta ES (2009) Biodiversity management in the face of climate change: a review of 22 years of recommendations. Biol Conserv 142(1):14-32

Hope M, McCloskey J, Hunt D, Crowley D, Bhloscaidh NM (2018) Innovation pathways to adaption for humanitarian and development goals: a case study of aftershock forecasting for disaster risk management. J Extreme Events 5(02n03):1850010

IPBES (2018) The IPBES regional assessment report on biodiversity and ecosystem services for Africa (eds: Archer E, Dziba L, Mulongoy KJ, Maoela MA, Walters M). Secretariat of the Intergovernmental Science-Policy Platform on Biodiversity and Ecosystem Services, Bonn. 492 pages. https://doi.org/10.5281/zenodo.3236178

IUCN (2008) Table 5: Threatened species in each country (Totals by Taxonomic Group)

IUCN (2019) Table 5: Threatened species in each country (Totals by Taxonomic Group)

Jones A (2017) Tourism in Botswana: tourist destinations in Botswana - wildlife. Amazon E-Book

Kari S, Kaboza Y (2019) Proceedings of the expert meeting "Transboundary co-operation for protecting the Cubango-Okavango River Basin and improving the integrity of the Okavango Delta World Heritage property", Maun, 3-4 June 2019. 36 pgs

Keys PW et al (2019) Anthropocene risk. Nat Sustain 2:667-673

Leadley P, Pereira HM, Alkemade R, Fernandez-Manjarrés JF, Proença V, Scharlemann JP, Walpole MJ (2010) Biodiversity scenarios: projections of 21st century change in biodiversity and associated ecosystem services. Secretariat of the Convention on Biological Diversity, Montreal. Technical Series no. 50, 132 pages

Lenton TM et al (2008) Tipping elements in the Earth's climate system. PNAS 105:1786-1793

Lenton TM, Livina VN, Dakos V, Van Nes EH, Scheffer M (2012) Early warning of climate tipping points from critical slowing down: comparing methods to improve robustness. Philos Trans $\mathrm{R}$ Soc A Math Phys Eng Sci 370(1962):1185-1204

Lichtenstein BB (2014) Generative emergence: a new discipline of organisational, entrepreneurial and social innovation. OUP US, New York 
Liu Z, Otto-Bliesner BL, He F, Brady EC, Tomas R, Clark PU, ... Erickson D (2009) Transient simulation of last deglaciation with a new mechanism for Bølling-Allerød warming. Science 325(5938):310-314

Lucas K, Renn O, Jaeger C, Yang S (2018) Systemic risks: a homomorphic approach on the basis of complexity science. Int J Disaster Risk Sci 9(3):292-305

MacPherson AJ, Gillson L, Hoffman MT (2019) Between-and within-biome resistance and resilience at the fynbos-forest ecotone, South Africa. The Holocene 29(11):1801-1816

McCarthy NA (2003) Demand for rainfall-index based insurance: a case study from Morocco, vol 106. International Food Policy Research Institute, Washington, DC

McCord PF, Dell'Angelo J, Bladwin E, Evans T (2017) Polycentric transformation in Kenyan water governance: a dynamic analysis of institutional and social-ecological change: polycentric transformation in Kenyan water governance. Policy Stud J 45(4):633-658

Midgley GF, Thuiller W (2011) Potential responses of terrestrial biodiversity in Southern Africa to anthropogenic climate change. Reg Environ Chang 11(1):127-135

Newbold T (2018) Future effects of climate and land-use change on terrestrial vertebrate community diversity under different scenarios. Proc R Soc B Biol Sci 285(1881):20180792

Oliver TH, Marshall HH, Morecroft MD, Brereton T, Prudhomme C, Huntingford C (2015) Interacting effects of climate change and habitat fragmentation on drought-sensitive butterflies. Nat Clim Chang 5(10):941-945

Polhill JG, Filatova T, Schlüter M, Voinov A (2016) Modelling systemic change in coupled socioenvironmental systems. Environ Model Softw 75:318-332

Porter AL, Garner J, Carley SF, Newman NC (2019) Emergence scoring to identify frontier R\&D topics and key players. Technol Forecast Soc Chang 146:628-643

Roundy PT, Bradshaw M, Brockman BK (2018) The emergence of entrepreneurial ecosystems: a complex adaptive systems approach. J Bus Res 86:1-10

Ryan AJ (2007) Emergence is coupled to scope, not level. Complexity 13(2):67-77

Saarinen J, Hambira WL, Atlhopheng J, Manwa H (2012) Tourism industry reaction to climate change in Kgalagadi South District, Botswana. Dev South Afr 29(2):273-285

Schot J, Kanger L (2018) Deep transitions: emergence, acceleration, stabilisation and directionality. Res Policy 47(6):1045-1059

Steffen W, Rockström J, Richardson K, Lenton TM, Folke C, Liverman D, ... Donges JF (2018) Trajectories of the Earth System in the Anthropocene. Proc Natl Acad Sci 115(33):8252-8259

Sterner T, Barbier EB, Robinson A (2019) Policy design for the Anthropocene. Nat Sustain 2:14-21

Tàbara JD, Frantzeskaki N, Hölscher K, Pedde S, Kok K, Lamperti F, Berry P (2018) Positive tipping points in a rapidly warming world. Curr Opin Environ Sustain 31:120-129

United Nations Framework Convention on Climate Change (UNFCCC) (2005) Report on the seminar on the development and transfer of technologies for adaptation to climate change: note by the Secretariat. FCCC/SBSTA/2005/8

van der Vleuten E (2019) Radical change and deep transitions: lessons from Europe's infrastructure transition 1815-2015. Environ Innov Soc Trans 32:22-32

Waisman H, Bataille C, Winkler H, Jotzo F, Shukla P, Colombier M, .. La Rovere E (2019) A pathway design framework for national low greenhouse gas emission development strategies. Nat Clim Chang 9(4):261

Walby S (2007) Complexity theory, systems theory, and multiple intersecting social inequalities. Philos Soc Sci 37(4):449-470

Wilson F, Moser G, Fallon D, Farrell CA, Müller C, Wilson D (2019) Rewetting degraded peatlands for climate and biodiversity benefits: results from two raised bogs. Ecol Eng 127:547-560

Winterbach HE, Winterbach CW, Somers MJ (2014) Landscape suitability in Botswana for the conservation of its six large African carnivores. PLoS One 9(6):e100202. https://doi.org/10. 1371/journal.pone. 0100202

Winterbach CW, Whitesell C, Somers MJ (2015) Wildlife abundance and diversity as indicators of tourism potential in Northern Botswana. PLoS One 10(8):e0135595. https://doi.org/10.1371/ journal.pone. 0135595 
Open Access This chapter is licensed under the terms of the Creative Commons Attribution 4.0 International License (http://creativecommons.org/licenses/by/4.0/), which permits use, sharing, adaptation, distribution and reproduction in any medium or format, as long as you give appropriate credit to the original author(s) and the source, provide a link to the Creative Commons license and indicate if changes were made.

The images or other third party material in this chapter are included in the chapter's Creative Commons license, unless indicated otherwise in a credit line to the material. If material is not included in the chapter's Creative Commons license and your intended use is not permitted by statutory regulation or exceeds the permitted use, you will need to obtain permission directly from the copyright holder.

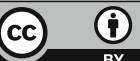

